\title{
Evolution of the muscular system in tetrapod limbs
}

Tatsuya Hirasawa ${ }^{1^{*}}$ (D) and Shigeru Kuratani $i^{1,2}$

\begin{abstract}
While skeletal evolution has been extensively studied, the evolution of limb muscles and brachial plexus has received less attention. In this review, we focus on the tempo and mode of evolution of forelimb muscles in the vertebrate history, and on the developmental mechanisms that have affected the evolution of their morphology. Tetrapod limb muscles develop from diffuse migrating cells derived from dermomyotomes, and the limb-innervating nerves lose their segmental patterns to form the brachial plexus distally. Despite such seemingly disorganized developmental processes, limb muscle homology has been highly conserved in tetrapod evolution, with the apparent exception of the mammalian diaphragm. The limb mesenchyme of lateral plate mesoderm likely plays a pivotal role in the subdivision of the myogenic cell population into individual muscles through the formation of interstitial muscle connective tissues. Interactions with tendons and motoneuron axons are involved in the early and late phases of limb muscle morphogenesis, respectively. The mechanism underlying the recurrent generation of limb muscle homology likely resides in these developmental processes, which should be studied from an evolutionary perspective in the future.
\end{abstract}

Keywords: Development, Evolution, Homology, Fossils, Regeneration, Tetrapods

\section{Background}

The fossil record reveals that the evolutionary rate of vertebrate morphology has been variable, and morphological deviations and alterations have taken place unevenly through history [1-5]. Sporadic geneses of new homologies, or units of evolutionary alterations, reflect this uneven evolutionary tempo. A synthesis of paleontology and evolutionary developmental biology may help to increase our understanding of how morphological homologies sporadically arise and why they are conserved in subsequent generations. However, in most cases, only post-embryonic morphology is observable in fossils, making it difficult to attribute observed evolutionary changes to certain developmental changes.

In the vertebrate body, skeletal muscles are connected to specific sites of connective tissues, such as bones, and these connections are generally unchanged after their initial formation. Thus, evolutionary changes in muscle connections, which can also be observed in fossil bones, correspond to changes in morphogenetic process, unlike

\footnotetext{
* Correspondence: tatsuya.hirasawa@riken.jp

'Laboratory for Evolutionary Morphology, RIKEN Center for Biosystems

Dynamics Research (BDR), 2-2-3 Minatojima-minami, Chuo-ku, Kobe, Hyogo

650-0047, Japan

Full list of author information is available at the end of the article
}

other morphological characters that may change during growth. Skeletal muscles thus exhibit clear advantages for the integration of paleontology and evolutionary developmental biology. This paper aims to summarize the current understanding of the evolution and development of skeletal muscles in the hopes of providing a basis for future studies. In particular, from the perspective of the role of developmental constraints in evolution [6], we focus on forelimb muscles, which were functionally diversified in tetrapod history. In regards to the interplay between developmental and functional constraints that shapes evolution, the conventional approach to modes of evolution [1] has addressed functional aspects, or adaptations, but has too often neglected developmental constraints as black boxes. We seek to remedy this deficit by suggesting a new framework for incorporating developmental constraints into researches on modes of evolution.

\section{Evolutionary history of tetrapod limb musculoskeletal systems}

In comparative anatomy, the homology of forelimb muscles among extant tetrapod species is identifiable based on gross anatomy, such as the connections between these muscles and bones or innervations, and the same set of names has 
been applied to different tetrapod classes [7-16], although there have been a few misidentifications in classical papers, e.g., for turtles [17]. Since the topographical relationships among limb muscles and their attachment sites are rather well conserved in extant tetrapods, reconstructions of muscles on the limb skeletons of fossil tetrapods has been achieved [18-24]. However, determining the oneto-one homology between tetrapod limb muscles and fish fin muscles has been more difficult [20, 24-27]. Extant tetrapods possess as many as $30-40$ individual muscles with specific names in their forelimbs, while extant fishes possess fewer than 10 descriptive pectoral fin muscles $[26,28,29]$. Clearly, substantial new homologies in the musculature were acquired during the fin-to-limb transition.

The evolution from fin muscles to limb muscles occurred deep in time (Fig. 1; the numerical values for ages follows the Geological Time Scale v.4.0 [30]). In the geological time scale, vertebrates first emerged in the fossil record around
520 million years ago [31-33], and the earliest fossil occurrences of paired fin-bearing gnathostomes are in the Early Silurian, 444-433 million years ago [34, 35]. The osteostracans, a stem-group of the gnathostomes, possessed only pectoral fins, but the endoskeletal elements were already present in their pectoral fins [36], suggesting that the fin musculoskeletal system originated in the common ancestor of osteostracans and crownward lineages (Fig. 1, arrow a).

Pelvic fins evolved in placoderms and crown-group gnathostomes [37], and from the latter, sarcopterygians evolved 423 million years ago (Ludlow Epoch of the Silurian) [38] (Fig. 1). Tetrapodomorphs evolved as a clade within the Sarcopterygia (Fig. 1), specifically sharing the last common ancestor with dipnoans (lungfishes) [39, 40]. Analysis of fossil trackways [41, 42] has suggested that limb-bearing tetrapods first walked on the ground around 400 million years ago, and body fossils of limb-bearing tetrapods have been discovered from the

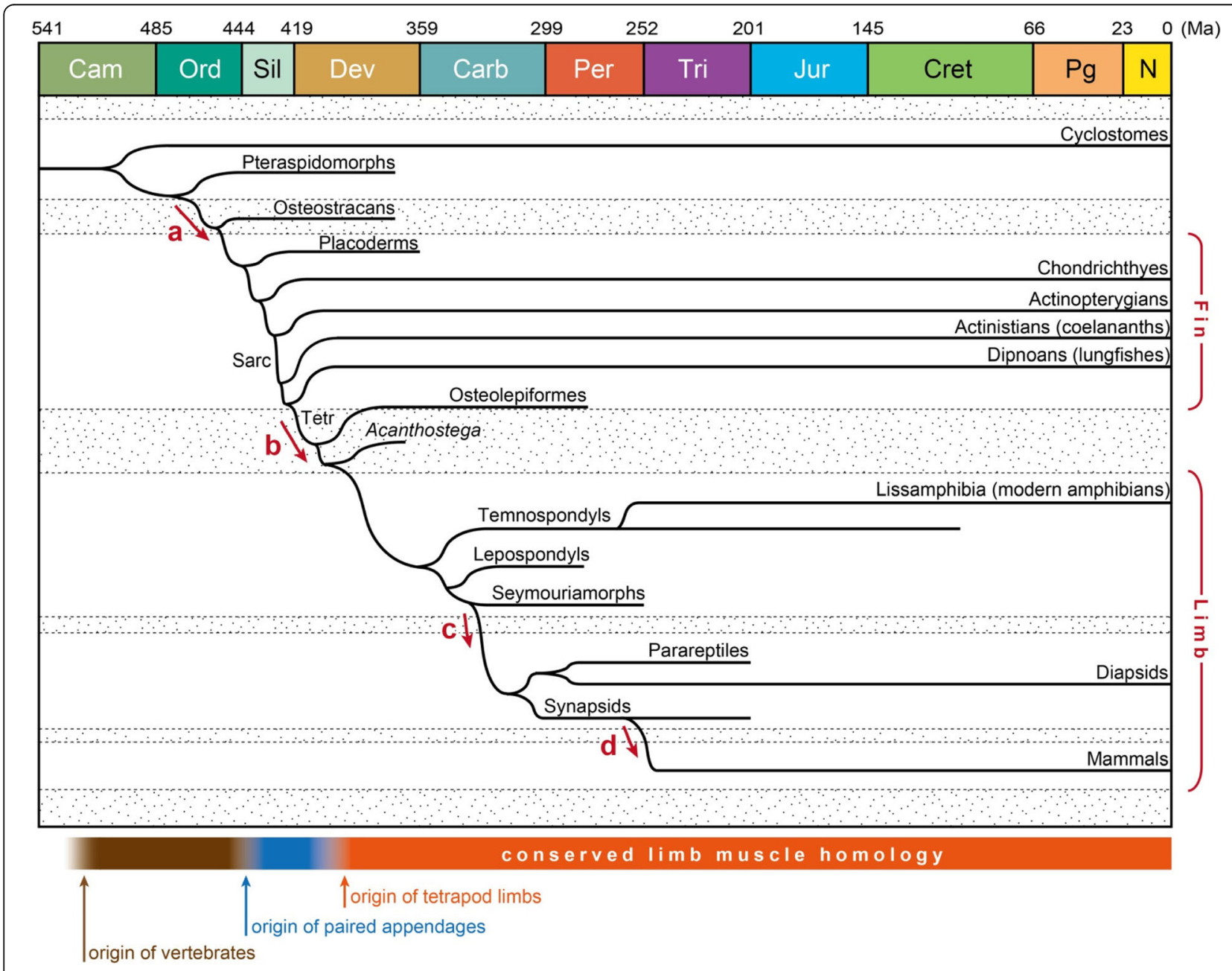

Fig. 1 Evolution of the limb muscles on the time-calibrated phylogenetic tree. a Acquisition of paired fins. b Establishment of the limb muscles and brachial plexus. c Loss of aquatic larval stage and regeneration capability. $\mathbf{d}$ Evolution of the diaphragm from a shoulder muscle. The stippled areas stand for putative transitional forms separating "grades" in fin/limb muscle evolution. The bar in the bottom shows the timescale of the limb muscle evolution. Sarc Sarcopterygia, Tetr, Tetrapodomorpha 
stratum of 375 million years ago [43, 44], providing physical evidence for the minimum age of the limb-bearing tetrapod history.

During the evolutionary transition from pectoral fin to forelimb, the ulna became as large as the radius, and the articular facets of the elbow and wrist joints turned, enabling the support of the body on a substrate [45-48], although the mobility of these joints was limited in the early limb-bearing tetrapods [49].

As for muscles, it is likely that the major morphological and topographical transitions took place concomitantly with the skeletal evolution, giving rise to the elbow and wrist joints of the forelimb. Indeed, the cross-section shape of the humerus and some muscle attachment sites on its surface in a basal limb-bearing tetrapod $[24,50]$ are consistent with this assumption. Thus, ancestral limb muscles had already emerged within the first $30 \%$ of the total history of vertebrate evolution ( $~ 520$ million years). In addition, whereas the fin-to-limb transition took place in a short period of the evolution of paired appendage (Fig. 1, arrow b), limb muscles were not significantly modified for around $85-90 \%$ of the whole paired appendage history (Fig. 1). Considering the period of time to be a proxy for the number of generations, the long absence of evolutionary deviation for limb muscles represents strong empirical evidence of both the robustness of limb muscle development and the singularity of its evolutionary origin.

Despite the conservation of limb muscle homology, the development of limb muscles is variable in timing and in the environment surrounding the progenitor cells. In amniotes, limb muscles develop almost in parallel with other skeletal muscles during embryonic development, and become functional before birth, whereas in many species of extant amphibians, the limbs and their muscles develop during larval stages [51-53]. Such relatively delayed development of limb muscles in amphibians has repeatedly led to the conclusion that these limb muscles are of lateral plate mesodermal origin $[54,55]$ unlike those of amniotes, which are of somitic origin [56-58]. However, in the current understanding, the limb muscles of amphibians are also of somitic origin [59-61]. In addition, concomitant with a unique Hox gene expression pattern $[62,63]$, the developmental sequence of limb skeleton $[64,65]$ and muscles [66] in urodele amphibians is opposite to that in amniotes and anuran amphibians. Moreover, extant amphibians, especially urodeles, show high capabilities of regeneration of limb musculoskeletal systems [67-69]. In these amphibians, limb muscle homology is recurrently formed both in normal development and in regeneration, providing further evidence of the robustness of limb muscle development.

Extant amphibians consist of only a fraction of several anamniote tetrapod lineages, and the phylogenetic position(s) of extant amphibians remains a matter of controversy. In one hypothesis, extant amphibians are all included in a single clade, the Lissamphibia, which evolved from the Temnospondyli, whereas the Amniota evolved from another clade, from which the extinct Seymouriamorpha and Lepospondyli also branched off [39, 70-72] (Fig. 1). An alternative hypothesis assumes the lepospondyl affinity of extant amphibians [73]. In both hypotheses, the data on these fossil anamniote taxa provide insights into the ancestral condition of the limb development.

Many stem anamniotes (basal temnospondyls, seymouriamorphs and lepospondyls), similarly to lissamphibians, had an aquatic, gill-bearing larval or juvenile stage [74-76]. Thus, the common ancestor of crown-group tetrapods likely had an aquatic larval/juvenile stage also. Although metamorphosis, which involves rapid morphological reorganization, evolved within the lissamphibian stem lineage $[4,77]$, it is possible that limb muscles developed in post-embryonic remodeling, at some point during the free-swimming larval or juvenile period in fossil anamniotes including the ancestors of amniotes, as suggested by data of basal temnospondyls [78-80], lepospondyls [80, 81], and the fin-bearing tetrapodomorph Eusthenopteron [82]. It is worth considering the possibility that the post-embryonic development of limb muscles seen in extant amphibians represents the ancestral state for tetrapods. Additionally, the possibility that the major evolutionary changes in developmental sequence could only have occurred in the early evolution of tetrapods [4] deserves consideration from the perspective of temporal change of evolvability.

The fossil record provides some indication for the development of the forelimb in the stem temnospondyls proceeding from the radial to the ulnar sides, as in the urodeles [83, 84]. Accordingly, the difference in developmental sequence between urodele and anuran/amniote limbs likely reflects two or more evolutionary changes in this developmental signature, rather than urodele synapomorphy.

Extant urodele amphibians are able to regenerate limb muscles $[85,86]$. Similar regeneration capabilities have been recognized in fossils of the stem temnospondyls and lepospondyls [84]. In addition, a recent study demonstrated that lungfishes, the sister group of the tetrapodomorphs, regenerate fins in a process similar to that in urodeles, by deploying gene regulatory networks that shared, at least in part, with those of urodeles, which suggests that the capacity for regeneration is plesiomorphic to tetrapodomorphs [87] (Fig. 1, arrow c). Although this regenerative competence was secondarily lost in amniotes and anurans, a common mechanism for recurrently generating limb muscles may underlie both development and regeneration. Future research on limb muscle regeneration may lead to a better understanding of the developmental mechanisms underlying limb muscle homology and its evolutionary origins. 


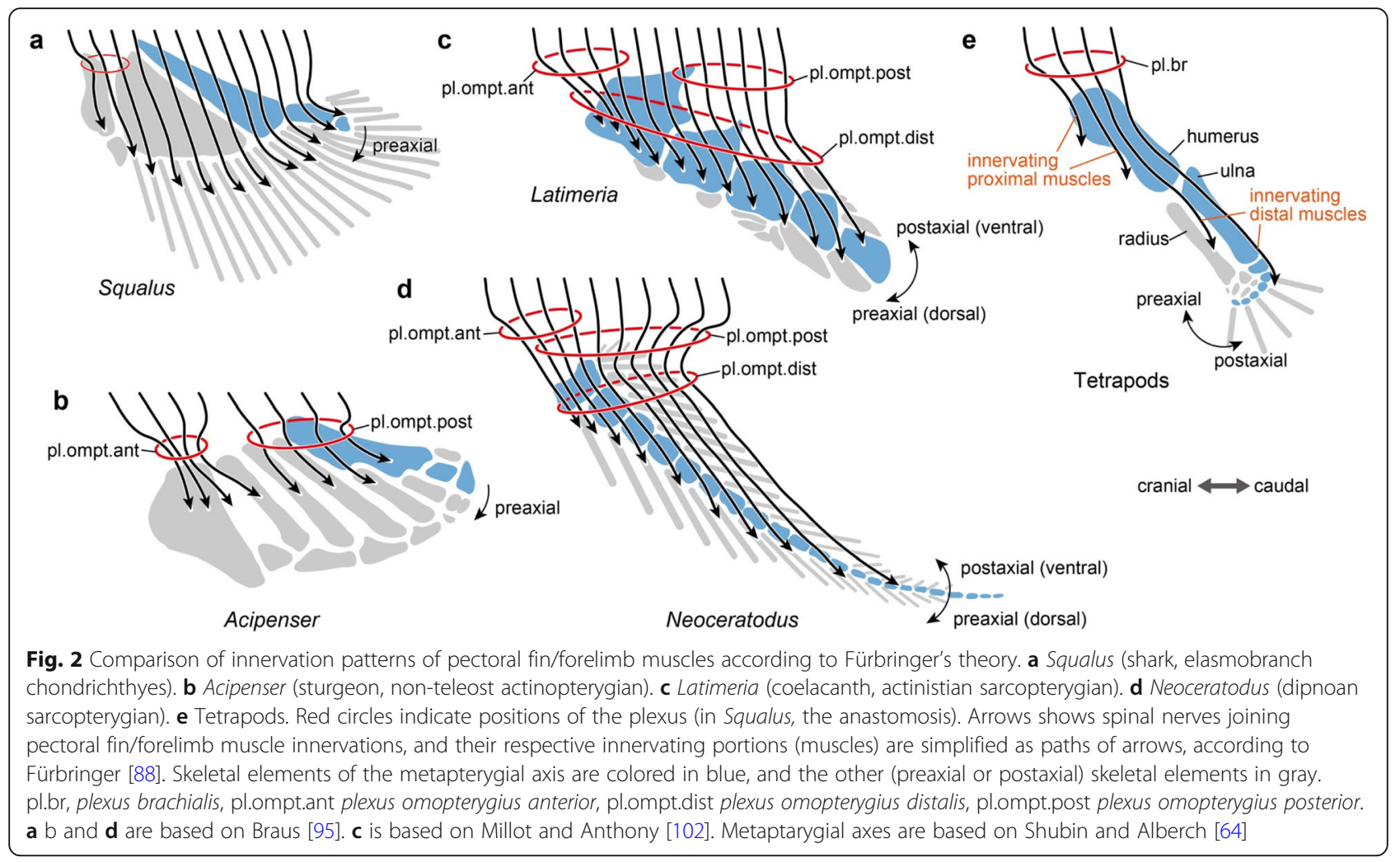

\section{Brachial plexus as an evolutionary novelty}

Fürbringer once emphasized that a motor nerve and its innervating skeletal muscle constitute a unitary structure (neuromotorische Apparate) [88]. In this scheme, the homology of limb muscles is linked with that of motor nerves, which extend from the central nervous system to the skeletal muscle, often forming anastomoses before innervation (Fig. 2).

Tetrapod forelimb muscles are innervated by nerves that branch off from the brachial plexus [25, 89-93]. In elasmobranchs, pectoral fin muscles are innervated by the main trunks of the spinal nerves, which lack extensive anastomoses [89, 94-97] (Fig. 2a). In the actinopterygians and non-tetrapod sarcopterygians (i.e., coelacanths and lungfishes), the fin muscles are innervated by plexusforming nerves (Fig. 2b-d). The plexuses of these osteichthyan fishes are composed of both occipital and spinal nerves [94, 95, 98].

According to the previous anatomical descriptions, a spectrum of complexity of anastomoses between fin muscle-innervating nerves is recognizable in osteichthyan fishes. However, most fish taxa show the shared feature that the plexus of nerves innervating the pectoral fin muscles can be subdivided anteroposteriorly into two parts; namely, the Plexus omopterygialis anterior and $\mathrm{Pl}$. omopterygialis posterior, although relatively inconspicuous anastomoses exist between them [95]. In embryonic development of the Australian lungfish (Neoceratodus forsteri), these two plexuses develop separately across the first rib [99]. In general, Pl. omopterygialis anterior is more elaborated than $\mathrm{Pl}$. omopterygialis posterior. In some actinopterygian species, $\mathrm{Pl}$. omopterygialis posterior is nothing more than a series of connections between nerves running independently $[95,100]$.

Besides the commonality of the two subdivided plexuses, there is a difference in plexus formation between the actinopterygian and sarcopterygian fishes. In sarcopterygian fishes, pectoral fin muscles develop distally to span the distal skeletal joints through tendinous insertions, whereas in actinopterygians, muscles cover only the proximal portion of the pectoral fin $[26,27,95,101]$. Concomitant with the differences in muscle distribution, unlike actinopterygians (Fig. 2b), sarcopterygian fishes possess an additional nerve plexus distal to $\mathrm{Pl}$. omopterygialis anterior and posterior within the muscles of the pectoral fin (Fig. 2c, d). Braus named this distal plexus as Pl. omopterygialis distalis [95] in his description of the Australian lungfish ( $N$. forsteri). A comparable plexus is also identifiable in the extant coelacanth (Latimeria chalumnae) [102].

For a wide range of tetrapod taxa, topographical patterns of brachial plexuses have been described in detail [12-16, 103-108]. Although inter- and intraspecific [109] variations exist, a comparable branching pattern is recognizable in tetrapod brachial plexuses; this has been used for homologizing forelimb muscles [25, 88]. Unlike pectoral fin muscles in fishes, forelimb muscles 
in tetrapods are innervated by only seven or fewer spinal nerves. In amniotes, brachial plexuses typically consist of four spinal nerves at the cervico-thoracic boundary of the axial musculoskeletal system [110]. Most limb muscles are innervated by nerve fibers composed of two or more roots of the plexus, or spinal nerves [88]. A set of these features is shared exclusively among tetrapods, suggesting that the brachial plexus evolved as a new unit of homology, or an evolutionary novelty.

Regarding the evolutionary origin of the brachial plexus and forelimb muscles, Fürbringer [88] once presented a hypothesis, which was supported by Braus [95] but has long since been forgotten. Fürbringer [88] proposed that in tetrapods most proximal limb muscles are innervated by nerves of anterior (preaxial) roots of the brachial plexus, whereas most distal limb muscles are innervated by nerves of posterior (postaxial) roots (Fig. 2e). In addition, he noted that the width of the appendage, in terms of number of associated spinal nerves (or somites), became narrowed at the fin-to-limb transition. Based on these observations, he formulated an evolutionary scenario from fin to limb: concomitant with the narrowing of the appendage, the antero-posterior axis of the innervation pattern and accompanying musculature in fish fins was shifted to the proximo-distal axis in tetrapod limbs, and this change brought about the dissolution of the segmentation pattern of spinal nerves and musculature. Although Fürbringer [88] did not specifically discuss skeletal homology, his theory is consistent with the evolutionary change in orientation of the metapterygial axis of skeletal elements across the fin-to-limb transition [64] (Fig. 2).

\section{Migratory muscle precursors}

Since the late nineteenth century, detailed observations of histological sections have been conducted for studying the development of limb muscle. Early scholars found that, in amniote embryos, limb muscles develop from migrating somitic cells, which are secondarily released from the segmentation pattern of somites [100, 111-114]. According to these observations of amniote embryos, the ventrolateral ends of the dermomyotomes, which extend toward the base of the limb bud, lose their epithelial structures at a certain developmental stage, and subsequently such de-epithelialized cells become dissolved into the mesenchyme of the limb bud (Fig. 3). This dissolution contrasts with the ventrally extending process of the dermomyotome, which forms the body wall muscles in amniotes. Within the limb bud, these migrating somitic cells can be distinguished histologically from the surrounding mesenchymal cells by their relatively large size of nucleus, possibly reflecting a less defined transcription pattern in chromatin dynamics [115], and they form cell masses, called "premuscle masses" $[55,113]$ or "muscle masses" [116, 117], before myogenesis. In the early phase of migration and

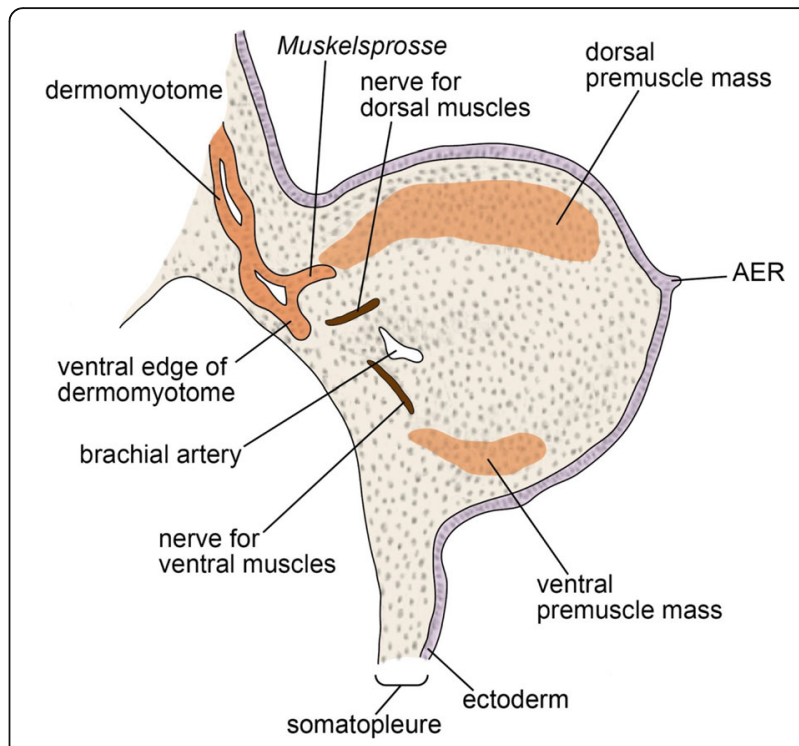

Fig. 3 Dorsal and ventral premuscle masses in the forelimb bud of Lacerta viridis (European green lizard). Modified from Corning [112]. AER apical ectodermal ridge

proliferation of the de-epithelialized dermomyotome-derived cell population, there are two-dorsal and ventral-premuscle masses within the limb bud (Fig. 3), and these premuscle masses are not distributed in the body wall, where the shoulder girdle develops [114]. As development proceeds, the medial portions of the premuscle masses expand toward the body wall. In other words, the premuscle masses initially intrude laterally into the limb bud but not the body wall, and then a part of the premuscle masses intrudes medially into the body wall $[113,114,118]$. A century later, this phenomenon was confirmed and termed the "in-out" mechanism [119]. Through this mechanism, the muscles spanning the limb skeleton and trunk (i.e., the pectoralis and latissimus dorsi muscles) develop $[113,114,118,119]$. In contrast, the muscles connecting the girdle skeleton with the trunk (i.e., the rhomboideus and serratus muscles) develop as part of the body wall muscles [114, 118-120]; thus, they have often not been classified as limb muscles [118]. In the above classification, true limb muscles develop from the premuscle masses that cancel the segmentation pattern and migrate to the limb bud, at least temporarily.

From the evolutionary perspective, this "diffuse migration of cells into the limb" [121] seen in amniote embryos has been compared with the developmental processes of fin muscles of fishes [99, 100, 114, 122-126] (Fig. 4). In anamniotes, the dermomyotome is not often segregated from the myotome, but the corresponding structure, whose ventral part extends ventrally to develop into fin and body wall muscles, has been recognized. In shark embryos, the segmentation pattern of the somites is maintained during the development of pectoral fin muscles, as 


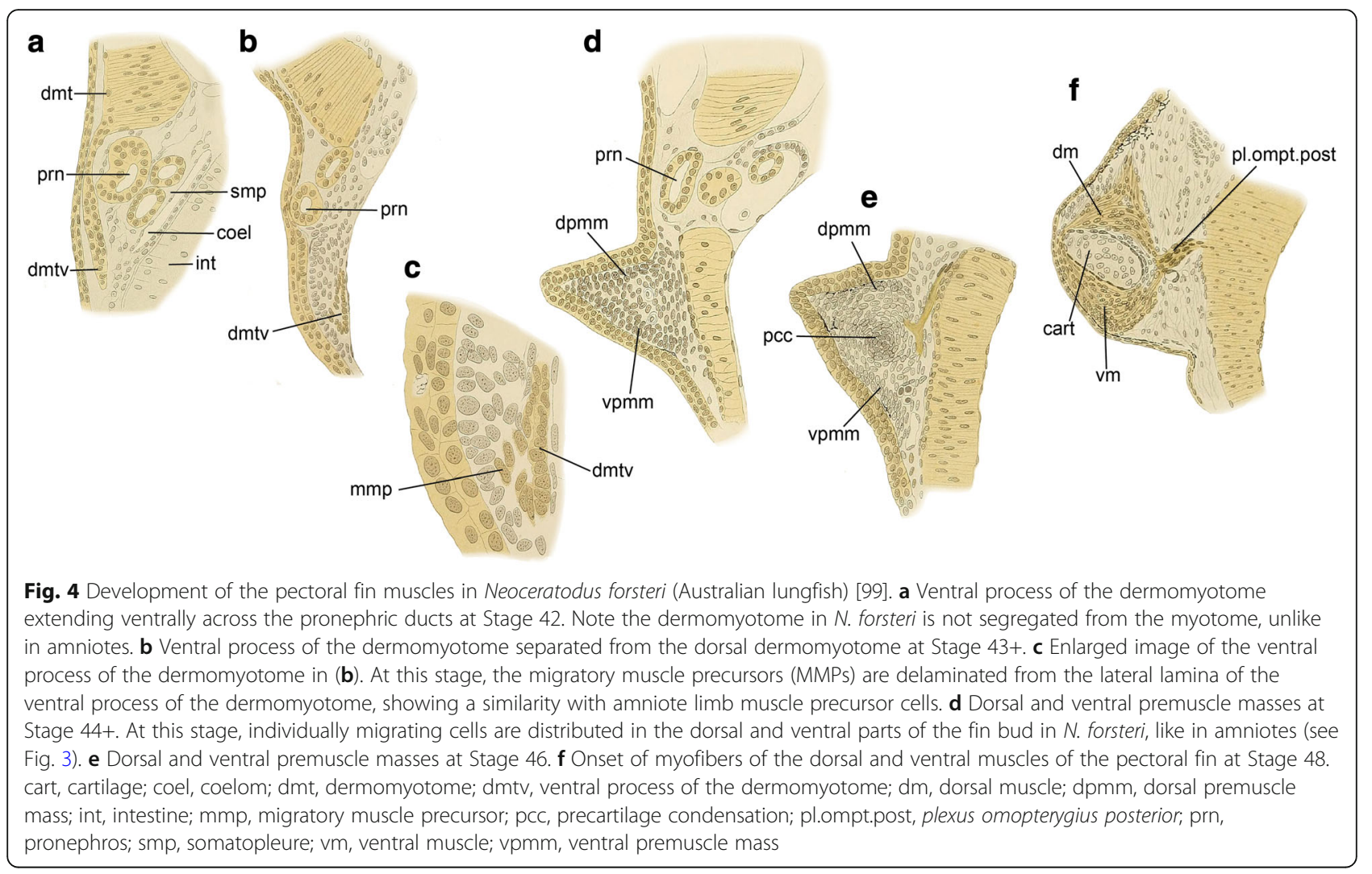

the epithelium of each myotomal sprout towards the fin bud ("Muskelsprosse," "Muskelknopsen," or "muscle bud," in classical reports) is not dissolved until immediately before myogenesis [122, 123, 126-128]. A recent study discovered that in shark embryos the epithelium of Muskelsprosse is once decomposed a short time before the epithelium of segregated Muskelsprosse becomes recomposed [129] (Fig. 5a, b). Therefore, the fin muscles of sharks develop not from direct extension, but from the recomposed epithelialized cell mass, which is pulled apart from the dermomyotomes. In contrast, in osteichthyan fishes (sturgeon [100]; teleosts [123, 130]; and Australian lungfish $[99,131])$, the epithelial structure of each myotomal extension is dissolved in the fin bud, and the Muskelsprosse-derived cells become mesenchymal before myogenesis (Fig. 4). With respect to this deepithelialization of the myotomal extension, Sewertzoff [114] noted the similarity between fin muscle development in osteichthyan fishes and limb muscle development in amniotes, and suggested that the difference between osteichthyan fin and amniote limb muscles reflects solely a heterochrony of myotomal de-epithelialization (Fig. 5c-e). As others have recognized [112, 124], the position of the myotomal de-epithelialization differs proximo-distally, even among amniotes; it occurs inside the limb bud in squamates (Figs. 3 and 5d), and at the boundary between the body wall and limb bud in birds and mammals (Fig. 5e).
From these lines of evidence, the developmental mode commonly observed in actinopterygian (sturgeon and teleosts) and sarcopterygian (lungfish: Figs. 4 and 5c) fishes may represent the ancestral condition for amniotes, although the evolutionary origin of the mesenchymal migration of fin/limb muscle precursor cells remains unclear. It is impracticable to infer the evolutionary relationship between the osteichthyan and chondrichthyan developmental modes (Fig. 5f), due to the lack of proper outgroup taxa, and the possibility remains that the developmental mode observed in sharks (Fig. 5a) represents a derived condition arising from the secondary loss of mesenchymal migration [129]. In the shark pectoral fin, two Muskelsprosse segments arise from a dermomyotome (Fig. 5b), whereas in osteichthyan pectoral fin/limb, a single Muskelsprosse segment arises [114]. It may be that the temporary decomposition of the epithelium of fin muscle primordium described in the shark by Okamoto et al. [129] reflects a process of Muskelsprosse bifurcation, which is chondrichthyan-specific.

In molecular biological studies of amniotes, both the cells undergoing diffuse migration into the limb bud and the precursor cells of hypobranchial muscle have been called "migratory muscle precursors (MMPs)" [132-136]; hypobranchial muscle precursor cells are also recognized as diffuse migrating cells in classical histological studies $[112,121,137]$. Before the initiation of myogenesis, these amniote MMPs migrate and proliferate while abutting 


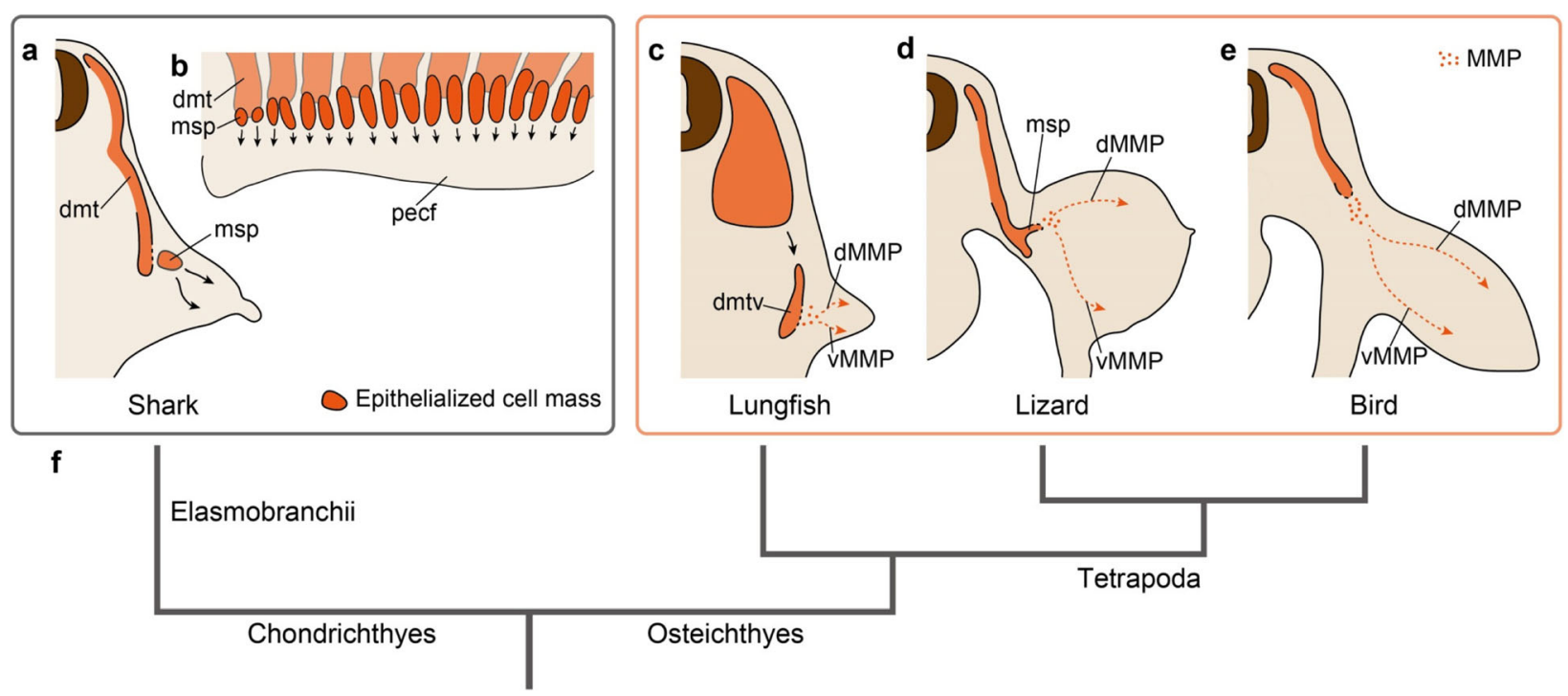

Fig. 5 Developmental processes of the premuscle masses in the pectoral fin/forelimb buds. a Development of the pectoral fin premuscle masses in the shark shown in a transverse section (based on Okamoto et al. [129]). b Bifurcation of each pectoral fin premuscle mass in the shark in lateral view (based on Okamoto et al. [129]). c Development of the pectoral fin premuscle masses in the lungfish shown in a transverse section (based on Semon [99]). d Development of the forelimb premuscle masses in the lizard shown in a transverse section (based on Corning [112]). e Development of the forelimb premuscle masses in the chicken shown in a transverse section. $\mathbf{f}$ Phylogenetic relationship among taxa illustrated in (a-e). dMMP, dorsal route of migratory muscle precursors (MMPs); dmt, dermomyotome; dmtv, ventral process of the dermomyotome; msp, Muskelsprosse; pecf, pectoral fin bud; vMMP, ventral route of MMPs

other mesenchymal cells, which later develop into connective tissues, including bones, ligaments, and tendons. According to mouse genetics studies (reviewed by [138-141]), two transcriptional factors, namely Pax3 [142] and Lbx1 [143-145], as well as the Hgf and c-Met signaling pathway $[134,146,147]$ are involved in the undifferentiated status of the MMPs. Lbx1 gene expression has also been observed in fin/limb muscle precursor cells of anamniote gnathostomes [52, 129, 148-150]. Unlike in limb muscle and diaphragm precursor cells [133], the diffuse migration of hypobranchial muscle precursor cells (probably except for the muscles of the secondary tongue [146], which newly evolved in tetrapods [151]) does not involve the Hgf and c-Met signaling pathway [152, 153].

From the evolutionary perspective, however, this genetic regulation had not necessarily been established at the evolutionary origin of the developmental mode involving the diffuse migration of the fin/limb muscle precursor cells. Moreover, such genetic regulation is subject to developmental system drift [154]; for instance, in the axolotl, the function of Pax3 in MMP migration is substituted by Pax7, allowing a gene loss of Pax3 from the genome [155]. For these reasons, it is inappropriate to define the MMP simply by the expression of $P a x 3, L b x 1$, and $c-M e t$, when comparing fin/limb muscle development among clades broader than amniotes. Indeed, in $L b x 1^{-/-}$mice, MMPs migrate to develop into a subset of muscles [144], indicating that $L b x 1$ expression is not essential for the cellular status of the
MMP. Accordingly, MMP is defined as a cell that meets two criteria: (1) a mesenchymally migrating and proliferating muscle progenitor cell; and (2) a muscle progenitor cell in which differentiation is arrested.

In amniotes, the migration of MMPs begins with an intrusion into the limb bud mesenchyme, which is solely of lateral plate mesoderm (LPM) origin. In limb muscle development, MMPs are produced from the somites adjacent to the limb bud through extrinsic cues from the limb bud, although depending on the Hox code, somites can exhibit intrinsic competence to produce putative MMPs (Lbx1-positive cells) [156]. Observations using scanning electron microscopy and histological sections at the limb level of chicken embryos, indicate that MMP cells pass through a cell-free space above the Wolffian duct, where extracellular matrix (ECM) fibrils are accumulated [157]. Although ECM plays an important role in cell migration in general [158], its influence on the MMP colonization of the limb-level LPM remains largely unknown. In transplantation experiments, the normal migration of MMPs occurs only when they encounter the LPM at the same or earlier developmental stage [56, 159]; from this it has been inferred that the intercellular space formed by ECM becomes restricted, eventually disturbing the MMP intrusion, at later developmental stages [159].

In addition to MMPs, endothelial precursors in the limb bud are derived from somites; their cell lineage is 
already separate from MMPs before their intrusion into the limb bud [160-162]. Prior to MMP colonization of the limb bud, somite-derived endothelial progenitors migrate into the limb bud, which is necessary for correct MMP migration [161, 163]. The pathfinding migration of endothelial precursors into the limb bud may affect the embryonic environment such that it accepts the migration of MMPs [163], although MMPs do not precisely follow the migratory route of endothelial precursors during migration within the limb bud [164].

As described above, MMPs take two separate migratory routes, namely via dorsal and ventral masses within the limb bud [114, 165, 166] (Figs. 3 and 4). Based on transplantation experiments disturbing the order of somites, MMPs do not possess intrinsic information about their destinations [167, 168]. Indeed, each limb muscle consists of cells derived from multiple somites [164, 167, 169, 170], as predicted in classical studies [88]. Sewertzoff [114] observed that the segmental character becomes lost through a concentration of MMPs (as well as spinal nerves) at the entrance of the limb bud. The craniocaudal convergence of the limb/fin bud during its early development [171, 172] probably leads to this concentration of MMPs coming from the somites beyond the width of the limb bud.

While our knowledge about the differentiation of skeletal muscle has steadily increased [141, 173], the morphogenesis, or topographical patterning, of the limb musculature has remained relatively unclear. Nevertheless, there is compelling evidence that MMPs develop into separate muscles in response to information from the LPM [160, 174-177]. Specifically, the distribution of LPM-derived interstitial muscle connective tissue (MCT) precursors, which express Osr1 and/or Tcf4 transcriptional factors, mediates the myogenic regionalization, or "pre-patterning" of muscles, by providing a muscle-specific ECM and a favorable signaling environment [178-182]. In addition, it has been reported that an ectodermal signal (Wnt6) affects the myogenic regionalization [183].

During the formation of the muscle pre-pattern, molecular interactions occur between the migrating MMPs and limb mesenchyme. According to studies of chicken embryos, spatiotemporally restricted distribution of the ligand ephrin-A5 within the limb mesenchyme provides a repulsive signal for migrating MMPs, which carry the tyrosine kinase receptor EPHA4 on their cell membranes [139, 184]. The migrating MMPs also carry the CXC chemokine receptor, CXCR4, and are attracted toward the limb mesenchyme, where the CXCR4 ligand (CXCL12; also known as SDF-1) is produced [185]. CXCL12/CXCR4 signaling is involved in the secondary intrusion of limb bud-dwelling MMPs into the body wall (i.e., the in-out mechanism) [186-188].

Subsequent to the pre-patterned muscle primordia, the morphogenesis of limb muscles involves subdivision into individualized muscles (muscle splitting); each muscle is then enveloped by a continuous dense irregular MCT called the epimysium. A dense regular MCT, the tendon, attaches the epimysium to the skeletal element enabling it to transmit the muscle's force to the skeletal element. Muscle fibers do not necessarily run parallel to tendons; in pennate muscles, for example, muscle fibers run at an angle to tendons and aponeuroses (tendinous sheets). In addition, another type of MCT, the fascia, which includes dense irregular and soft (adipose and areolar) MCTs [189], surrounds and intervenes between the epimysia and tendons.

There is compelling evidence that muscle splitting is affected by the blood vessels within the limb bud [190, 191]. In the developing limbs of chickens, the vasculature pattern is formed independent of the distribution of MMPs; muscle splitting subsequently occurs along the zone occupied by endothelial cells [191]. During this process, probably through the increased production of ECM induced by PDGFB (platelet-derived growth factor B) from endothelial cells, the MCT cells assemble at the future splitting zone, eventually subdividing the premuscle masses [191]. Whether this developmental process occurs in fin buds remains unclear, as observations have been limited to the marginal veins $[100,192]$. In amniotes, blood vessels in the limb bud are composed of endothelial cells, which are differentiated from migrating somitic cells $[162,193]$. Because the involvement of migrating somitic cells in the formation of the blood vessels within fin buds has not been studied in any fishes, it is impossible to determine the evolutionary origin of the migrating endothelial precursors. It should be noted that a recent detailed study of the ventral end of the dermomyotome at the pectoral fin level in shark embryos [129] did not identify any migrating endothelial precursors.

In humans, the topography of major arteries supplying the forelimb muscles shows intraspecific variation [194-198], implying that the pattern of blood vessels is not a single determinant of muscle splitting in the limb bud. Indeed, the topography of embryonic blood vessels is flexible in response to the local environment, because it is formed under the influence of oxygen and nutrient demand, as well as blood flow [199]. In the developing forelimb bud of mammals [200] and birds [201-203], a web of fine vessels (i.e., the capillary network) appears uniformly at first, and then becomes remodeled to establish branching thick vessels through poorly understood mechanisms, which may allow a certain level of variability.

Nevertheless, there is a modest evolutionary relationship between arterial and muscular topographies. In the limb-to-flipper evolution of the cetaceans, corresponding to fixations of elbow and wrist joints, the forearm and manual muscles became reduced, such that some muscles, including the biceps brachii, brachialis and intrinsic manual muscles, were lost [204-208]. Among tetrapods, cetaceans possess the simplest topography of forelimb 
arteries; unlike in other tetrapods, the branching of the brachial artery near the elbow joint is absent [209, 210], suggesting that loss of muscle splitting correlates with simplification of arterial topography during evolution. The evolutionary reduction of forearm and manual muscles is also recognizable in the flippers of penguins; however, major muscles are still retained as diminutive forms [211], implying that muscle splitting during embryonic development has been evolutionarily conserved. Unlike in cetaceans, the arterial topography of the penguin flipper is consistent within the range of variability of most tetrapods [211], indicating that simplification of the arterial topography may not be correlated with the decreased oxygen consumption of the muscles supplied by these arteries.

The evolutionary relationship between the arterial and muscular topographies may also be present in part in non-tetrapod sarcopterygians. In the extant coelacanth Latimeria, the main trunk of the pectoral fin artery bifurcates at a point just medial to the second pronator muscle [212]. Since this point corresponds to the elbow joint of tetrapods [27], the bifurcating arteries are likely homologous with the radial and ulnar arteries of tetrapods.

Muscle splitting in the forelimb bud is not identical to that in the hind limb bud, although both limb muscles develop from similar premuscle masses. In studies of chicken [213, 214] and mouse [215, 216], a paired-type homeodomain transcriptional factor Pitx1 is responsible for the morphological identity of the hind limb, and misexpression of Pitx 1 in the LPM-derived forelimb bud mesenchyme results in homeotic transformation from forelimb- to hind limb-like muscle patterns. A similar homeotic transformation has also been identified in a human congenital anomaly, Liebenberg syndrome, the etiology of which involves a genomic change at the PITX1 locus [217]. These studies on Pitx1 suggest that limb muscle patterns emerge in accordance with information within the limb bud mesenchyme prior to the migration of the MMPs.

Although muscle splitting plays a central role in the patterning of limb muscles, it should be noted that individual muscles are not always formed directly through the muscle splitting of a premuscle mass [218]. For example, after muscle splitting, multiple muscle primordia fuse into a single muscle (secondary fusion) during the development of pectoralis and brachialis muscles in humans [218]. Furthermore, during development of the human extensor digiti minimi muscle, primordia are formed at the fourth and fifth digits; however, the primordium at the fourth digit later disappears [218]. These secondary remodeling processes of developing muscles are indispensable to the formation of taxon-specific muscle topography.

During the development of individual muscles, multiple myoblasts fuse to form multinucleated myotube cells [219]; subsequently additional myoblasts fuse to the myotube, eventually forming myofiber cells [220]. Satellite cells, which are derived from the shared cell population with myoblasts, are also incorporated in each muscle and reside between the sarcolemma and basement membrane of myofibers [141, 221].

The process of limb muscle regeneration shows similarities with the developmental process. In amniotes, satellite cells proliferate and differentiate into myoblasts during skeletal muscle regeneration [141, 221-223]. At the differentiation from the satellite cell to myoblast, $L b x 1$ is transiently expressed [224], reminiscent of the differentiation from the MMP to myoblast in embryonic development. Subsequently, differentiating satellite cells migrate to the regenerating site while interacting with $\mathrm{MCT}$ expressing Tcf4 [223]. Ephrins produced by neighboring myofibers also likely provide repulsive signals for migrating satellite cells [222]. These satellite cell behaviors are suggestive of commonality with MMP migration in the limb buds.

As mentioned earlier, urodeles are able to regenerate an amputated limb, and the topography of limb muscles is recurrently formed during this process $[67,225]$. In urodeles, satellite cells are the source for regenerated limb muscles before metamorphosis; however, after metamorphosis, regenerated limb muscles are derived from de-differentiated myofiber cells $[85,86,226]$. Although the mechanism of the recurrent generation of individual muscles in an amputated limb remains unclear, it may be important for understanding how limb muscle homology is maintained during evolution.

\section{Interaction between developing muscles and tendons in amniotes}

The tendon is a dense, highly organized fibrous connective tissue, composed predominantly of type I collagen, which transmits a uniaxial force between a bone and a muscle [181, 227, 228]. It is very similar to the ligament, which is connected solely to bones [229]. At the junction between the bone and the tendon or ligament, there is a transitional tissue, or fibrocartilage, in which chondrocytes are enclosed, and the fibers of tendon or ligament connect to the periosteum [230]. In the development of this junction, a common progenitor cell population that co-express Sox 9 and scleraxis (Scx; a basic helix-loop-helix (bHLH) transcriptional factor) differentiates into tendon or ligament cells (tenocytes or ligamentocytes, respectively) or chondrocytes at the attachment site of the bone (enthesis) [231-233]. However, the patterning of the tendon is not necessarily coupled with that of the skeleton; rather it forms under shared cues with the muscle patterning [234]. On the muscle side, the fibers of the tendon connect to the epimysium and perimysium; i.e., the MCTs surrounding the individual muscles and bundles of myofibers, respectively. The junction between the muscle and tendon initially form as a specialized region of the epimysium and later become contiguous with the perimysium [235]. 
The formation of individual muscles in the limb is intimately related with tendon development. According to the experiments focusing on tendon development in the absence of muscle, and vice versa, in chicken embryos, the differentiation of tendon and muscle progenitors occur independently of each other, but the subsequent muscle splitting and segregation of tendon primordia into individual tendons require reciprocal interactions between the developing muscle and tendon [236]. These interactions involve Fgf signaling in chicken embryos [237-239]. Such interactions are responsible not only for the topography of the muscles, but also for the shape of muscle bellies sculptured by myofiber apoptosis [240]. In mice, tendons in the limb, in particular in the zeugopod (forearm), become elongated as the zeugopod skeleton elongates, after the establishment of the connection between muscle and tendon [241]. Late in this morphogenetic process, the flexor digitorum superficialis muscles, which initially develop in the autopod (manus), become translocated into the zeugopod [241, 242].

Our current understanding of tendon development is based largely on studies of Scx, which is a specific marker for tendons and ligaments [238, 243-248]. Although some signaling molecules, including transforming growth factor $\beta(\operatorname{Tgf} \beta)$ and $\mathrm{CXC}$ chemokines, likely regulate differentiation and maintenance of $S c x$-expressing tendon progenitors $[249,250]$, how the tendon progenitors are specified in embryonic mesenchyme remains unsolved.

\section{Interaction between developing muscles and motoneuron axons in amniotes}

Although the evolutionary conservation of the topography of the brachial plexus and peripheral branching axons has attracted the attention of researchers in comparative anatomy, the morphogenesis of limb-innervating nerves remains for the most part unclear.

In embryonic development, the brachial plexus is formed at the "plexus mesenchyme" [251] (Fig. 6), which consists of LPM at the base of the limb bud. Gdnf (glial cell line-derived neurotrophic factor) is transiently expressed in the plexus mesenchyme, and likely supports neurons while their axons organize in the plexus [251-253]. The migrating MMPs are diverged into the dorsal and ventral premuscle masses at the plexus mesenchyme [251], suggesting that the plexus mesenchyme also affects the MMP migration. In addition, the fact that the development of the latissimus dorsi and cutaneous maximus muscles, both of which develop through the in-out migration of MMPs from the limb bud, requires Gdnf after the formation of the plexus [252] should be noted in light of the involvement of the plexus mesenchyme in MMP migration.

The timing of the first contact between nerve axons and developing muscles varies among tetrapods. In mammals and anurans, nerve axons enter the limb premuscle masses almost concurrent with premuscle mass formation

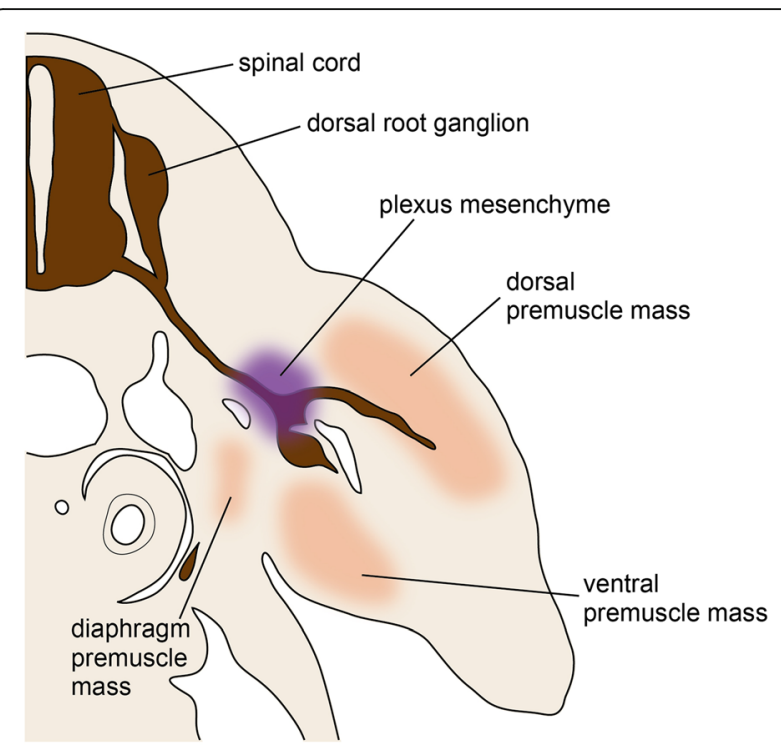

Fig. 6 Schematic drawing of the plexus mesenchyme in the E10.5 mouse. Based on Wright and Snider [251]. The plexus mesenchyme expressing Gdnf is of lateral plate mesodermal origin, and does not involve muscle precursor cells

[254-256], while in birds the axons remain at the plexus region prior to the onset of primary myotube formation $[257,258]$. Considering this interspecific difference, interaction between the nerve axon and developing muscle may not be required for the morphogenesis of limb muscles before the primary myotube formation.

The limb-innervating motoneurons are specified according to the expression pattern of Hox genes in the spinal cord [259-264]. Although the limb muscle-innervating motoneurons are specified at the level of MMP-producing somites along the body axis, experimental perturbations have indicated that the specification of these motoneurons are independent of those of MMP-producing somites [265]. The axons of the limb muscle-innervating motoneurons extend to innervate the corresponding muscles (Fig. 7) in accordance with the surrounding environment, as shown by experimental perturbations of avian embryos [177, 266-269]. The correspondence between the motoneurons and each muscle (Fig. 7) is determined prior to the innervation, as exemplified by experiments displacing motoneuron pools in the chicken embryo by craniocaudally reversing the spinal cord at the lumbosacral level [266], as well as by perturbing the Hox code in the spinal cord at the brachial level [259].

Detailed observation of the chicken hind limb has shown that, in the limb mesenchyme, the axons pass across the domain where glycosaminoglycans are thin, so the axons do not pass the domains where cartilages later develop [270]. Similarly, a recent study of various amniote embryos suggested that a class 3 semaphorin, Sema3A, secreted from chondrocytes provides a repulsive signal for axonal 


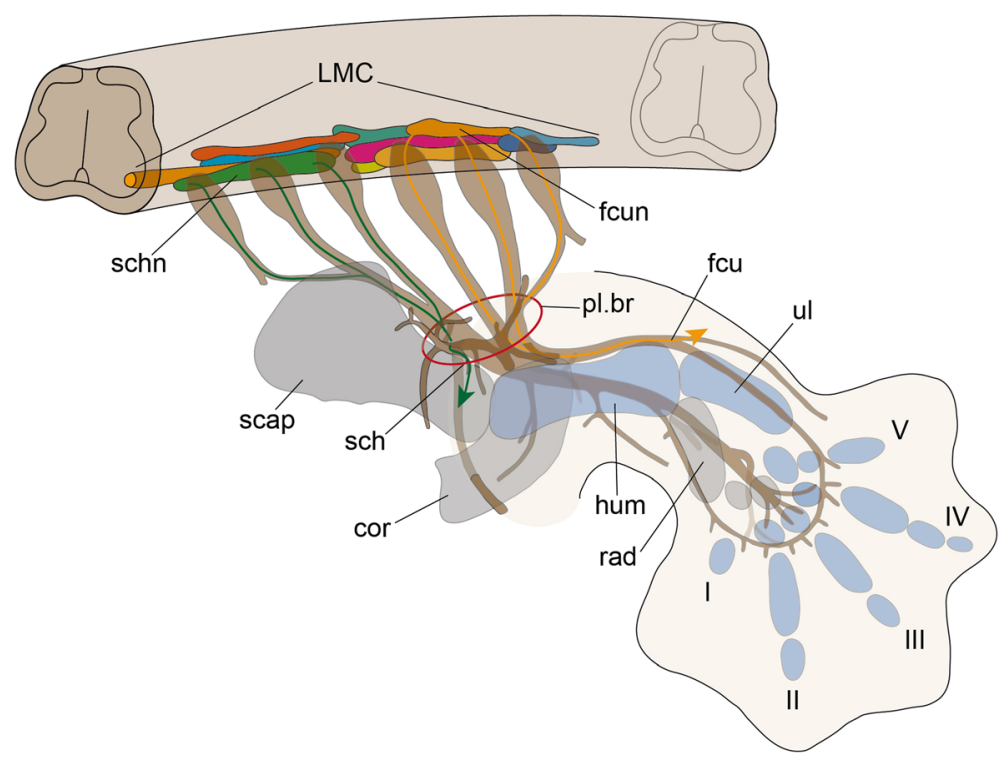

Fig. 7 Columnar organization of motor neuron pools and the topography of nerves innervating limb muscles in tetrapods. Motoneuron columnar organization is based on the study using the chicken [259]. Topography of nerves and skeletal elements of Tarentola (Ascalabotes) fascicularis (gecko) illustrated in Sewertzoff [114] is shown as a representative. Skeletal elements of the metapterygial axis are colored in blue, and the other (preaxial) skeletal elements in gray. Nerves for the scapulohumeralis (green) and flexor carpi ulnaris (orange) muscles are shown as examples of correspondences between motoneuron pools and their respective target muscles. cor, coracoid; fcu, nerve for the flexor carpi ulnaris muscle; fcun, motoneuron for the flexor carpi ulnalis muscle; hum, humerus; scap, scapula; I-V, digits I-V; LMC, lateral motor column; sch, nerve for the scapulohumeralis muscle; schn, motoneuron for the scapulohumeralis muscle; pl.br, plexus brachialis; rad, radius; ul, ulna

guidance [271]. In contrast, $\beta$-catenin stabilization in muscle provides an attractive signal to the axons $[272,273]$. Considering the hypothesis of Fürbringer [88] regarding the evolutionary change that brought about the brachial plexus, the possibility that the pathfinding of the axons follows the regionalization associated with the metapterygial axis in the limb mesenchyme (Fig. 7) deserves consideration.

In vertebrates, at the junction between a motoneuron axon and muscle, there is a specific type of synapse, namely the neuromuscular junction, in which acetylcholine (ACh) functions as an excitatory neurotransmitter to cause muscle contraction [274]. Prior to the arrival of the motoneuron axon, ACh receptors (AChRs) are aggregated to form multiple clusters (aneural AChR clusters) at a region in the middle of the myofibers. This AChR-aggregated area is the foundation of the neuromuscular junction, in that the nerve terminals arrive at certain aneural AChR clusters to initiate synaptogenesis [274]. Until the completion of the neuromuscular junction formation, which proceeds postnatally for 2 weeks in the mouse, a single myofiber is transiently innervated by axons of multiple motoneurons, although it later becomes innervated by only a single motoneuron axon through reciprocal interactions between the muscle and synapse plus terminal Schwann cells [275-279].

Experiments involving removal of nerves in the chicken embryo have demonstrated that interaction with nerves is not responsible for muscle splitting [280, 281]. In contrast, neuromuscular junction formation is involved in the later phase of development after the formation of primary myotubes, as contractions of muscles are responsible for the morphogenesis of muscles [250, 282, 283] and the bony ridges at muscle attachment sites [284].

\section{Observed variability in the forelimb muscles}

The developmental process explained above allows modest intraspecific variability in morphology of forelimb muscles. Since forelimb muscles are present as paired structures, intraspecific variations showing fluctuating asymmetry $[285,286]$ are expected to originate from developmental fluctuation rather than the genetic background. Indeed, such variations have been reported in human anatomy; e.g., the muscular axillary arch [Muskulöser Achselbogen] and sternalis muscle as variations of the pectoralis muscle [287-295]. In another case, extensive fluctuating asymmetry has been reported for wing muscles of the flightless bird, emu (Dromaius novaehollandiae), suggesting relaxed stability of the developmental mechanism in the vestigial limb [296]. Future studies of the variability observed in limb muscles may improve our understanding of the relationship between developmental fluctuation and evolvability.

\section{Diaphragm: an evolutionary novelty of the mammalian lineage}

As mentioned above, after their evolutionary origin, forelimb muscles have evolved without drastic 
modification. However, recent studies of evolutionary changes in forelimb position along the body axis have found that the mammalian diaphragm likely evolved from a shoulder muscle, through a partial duplication of the forelimb MMP population [110, 297]. In particular, comparison of brachial plexuses among amniotes suggests that the diaphragm evolved from the subscapular muscle of the ancestor [110] (Fig. 8a, b). In the evolution toward mammals, the supracoracoid muscle diverged into two muscles, namely the supra- and infraspinatus muscles [19], and it is possible that the evolutionary origin of these two muscles coincided with that of the diaphragm through a divergence from the ancestral subscapular muscle (Fig. 8a, c).

Some classical papers of comparative anatomy $[298,299]$ have suggested that the diaphragm evolved from the rectus cervicus muscles, namely hypobranchial muscles, which also develop from MMPs. However, recent studies of developmental biology have highlighted commonalities between the diaphragm and forelimb muscles: both these muscles develop in LPM-derived mesenchyme expressing Tbx5 and $H g f$, unlike the hypobranchial muscles [119, 133, 152, 153]. In addition, a few clinical cases of associated movements between the diaphragm and some forelimb muscles (Erb's palsy) in patients who experienced birth injuries of the brachial plexus have been reported [300-302]. As suggested by Oosuga [303], it is possible that these cases reflect the forelimb muscle-like identity of the diaphragm.
As a candidate exception to forelimb muscle homology, the diaphragm offers an exclusive opportunity for understanding when and how a drastic modification was possible in the evolutionary history after the establishment of an evolutionary novelty, or a new developmental constraint.

\section{Conclusions}

1. At the pectoral fin-to-forelimb transition, the number of muscles increased, while the number of spinal nerves innervating these muscles decreased. The brachial plexus is an evolutionary novelty of tetrapods. Within the tetrapod lineage, limb muscle homology has been largely conserved.

2. Forelimb muscles develop from diffuse migrating somitic cells, or MMPs. The limb muscle homology is generated mainly through subdivision of myoblast masses (muscle splitting). The LPM-derived limb mesenchyme likely provides the information for the proper distribution of MMPs, and subsequently the MCTs differentiated from the LPM-derived limb mesenchyme subdivide each myoblast mass into individual muscles. Development of blood vessels plays some role in the latter process.

3. The reciprocal interaction with tendon progenitors is necessary for the morphogenesis of individual

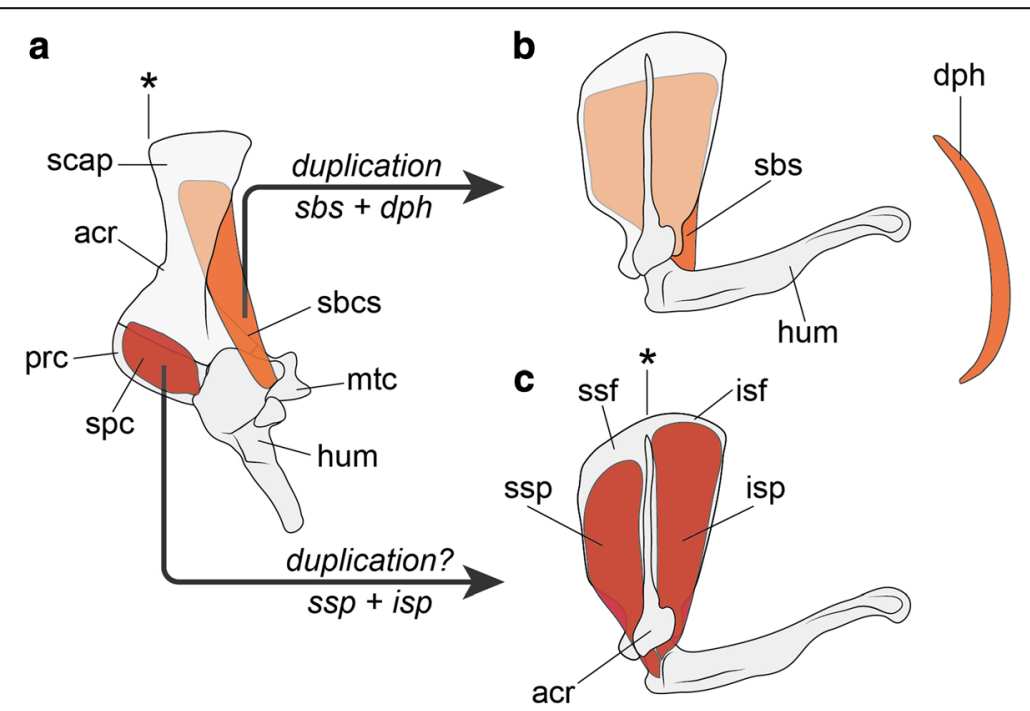

Fig. 8 Putative evolutionary origin of the diaphragm through a partial duplication of MMP population. Based on Hirasawa and Kuratani [110]. Left lateral views. a Subcoracoscapular muscle (subscapular muscle-homolog) of the dorsomedial forelimb muscle group and the supracoracoid muscle of the ventrolateral forelimb muscle group in a Pelycosaur-grade taxon, Dimetrodon (based on Romer [19]). b Subscapular muscle and the diaphragm, which evolved from the subcoracoscapular muscle of Pelycosaur-grade ancestors, in an extant mammal, Didelphys (based on Jenkins and Wejs [304]). c Supraspinatus and infraspinatus muscles in Didelphys. Note the cranial margin of the scapula $\left(^{*}\right)$ in (a) corresponds to the border between the supraspinatus and infraspinatus fossae $\left(^{*}\right)$ in (c) $[117,305]$. acr, acrominon; dph, diaphragm; isf, infraspinatus fossa; isp, infraspinatus muscle; hum, humerus; mtc, metacoracoid; prc, procoracoid; sbcs, subcoracoscapular muscle; sbs, subscapular muscle; scap, scapula; spc, supracoracoid muscle; ssf, supraspinatus fossa; ssp, supraspinatus muscle 
muscles, but the tendon and muscle progenitors begin their differentiation independently of each other.

4. Although the topography of the brachial plexus and the relationship between the nerves and their innervating forelimb muscles are evolutionarily conserved, the developmental mechanism recurrently generating them remains largely unclear, and should be the subject of future analyses.

5. In addition to further studies on the developmental mechanism recurrently generating the forelimb muscle homology, particularly focusing on MCTs and tendons, studies on intraspecific variability of the forelimb muscle morphology and research on the diaphragm as a putative derived forelimb muscle will lead to our better understanding of the role of developmental constraints in evolution.

\section{Acknowledgements}

The authors thank Rie Kusakabe for discussion and the two anonymous reviewers for comments that improved the manuscript.

\section{Funding}

This work was supported by JSPS KAKENHI grant numbers JP15K21628, JP17K18354 (to T.H.), 15H02416, and JP17H06385 (to S.K.), and a Naito Grant for the Promotion of Focused Research (The Naito Foundation) (to S.K.).

\section{Authors' contributions}

TH conceived the plan and wrote the original draft. SK reviewed and edited the drafts. Both authors read and approved the final version of the manuscript.

\section{Ethics approval and consent to participate}

Not applicable.

\section{Consent for publication}

Not applicable.

\section{Competing interests}

The authors declare that they have no competing interests.

\section{Publisher's Note}

Springer Nature remains neutral with regard to jurisdictional claims in published maps and institutional affiliations.

\section{Author details}

'Laboratory for Evolutionary Morphology, RIKEN Center for Biosystems Dynamics Research (BDR), 2-2-3 Minatojima-minami, Chuo-ku, Kobe, Hyogo 650-0047, Japan. ${ }^{2}$ Evolutionary Morphology Laboratory, RIKEN Cluster for Pioneering Research (CPR), 2-2-3 Minatojima-minami, Chuo-ku, Kobe, Hyogo 650-0047, Japan.

Received: 25 June 2018 Accepted: 4 September 2018

Published online: 20 September 2018

\section{References}

1. Simpson GG. Tempo and mode in evolution. New York: Columbia University Press; 1944.

2. Ruta M, Wagner PJ, Coates MI. Evolutionary patterns in early tetrapods. I. Rapid initial diversification followed by decrease in rates of character change. Proc R Soc B. 2006;273:2107-11.

3. Wagner PJ, Ruta M, Coates MI. Evolutionary patterns in early tetrapods. II. Differing constraints on available character space among clades. Proc $\mathrm{R}$ Soc B. 2006;273:2113-8.

4. Organ CL, Cooper LN, Hieronymus TL. Macroevolutionary developmental biology: embryos, fossils, and phylogenies. Dev Dyn. 2015;244:1184-92.
5. Cantalapiedra JL, Prado JL, Hernandez Fernandez M, Alberdi MT. Decoupled ecomorphological evolution and diversification in Neogene-quaternary horses. Science. 2017;355:627-30.

6. Maynard Smith J, Burian R, Kauffman S, Alberch P, Campbell J, Goodwin B, Lande R, Raup D, Wolpert L. Developmental constraints and evolution. Q Rev Biol. 1985;60:265-87.

7. Cuvier G. Leçons d'Anatomie Comparée, tome I. Paris: Baudouin, Imprimeur de L'Institut National des Sciences et des Arts; 1799.

8. Owen RC. On the anatomy of vertebrates. Volume 1: fishes and reptiles. London: Longmans, Green, and Co.; 1866.

9. Owen RC. On the anatomy of vertebrates. Volume 2: birds and mammals. London: Longmans, Green, and Co.; 1866.

10. Owen RC. On the anatomy of vertebrates. Volume 3: mammals. London: Longmans, Green, and Co.; 1868.

11. Parker WK. A monograph on the structure and development of shouldergirdle and sternum in the vertebrata. London: R. Hardwicke; 1868.

12. Fürbringer M. Zur vergleichenden Anatomie der Schultermuskeln. I Theil. Jena Z Naturwiss. 1873;7:237-320.

13. Fürbringer M. Zur vergleichenden Anatomie der Schultermuskeln. II Theil. Jena Z Naturwiss. 1874;8:175-280.

14. Fürbringer M. Zur vergleichenden Anatomie der Schultermuskeln. III Theil. Gegenbaurs Morphol Jahrb. 1876;1:636-816.

15. Fürbringer M. Zur vergleichenden Anatomie des Brustschulterapparates und der Schultermuskeln. IV. Teil. Jena: Gustav Fischer; 1900.

16. Fürbringer M. Zur vergleichenden Anatomie des Brustschulterapparates und der Schultermuskeln. V. Teil. Jena: Gustav Fischer; 1902.

17. Bojanus LH. Anatome testudinis Europaeae. Vilnae: Impenis auctoris, typis Josphi Zawadzki; 1819-1820.

18. Gregory WK, Camp CL. Studies in comparative myology and osteology. No. III. Bull Am Mus Nat Hist. 1918;38:447-563.

19. Romer AS. The locomotor apparatus of certain primitive and mammal-like reptiles. Bull Am Mus Nat Hist. 1922;46:517-606.

20. Romer AS. Pectoral limb musculature and shoulder-girdle structure in fish and tetrapods. Anat Rec. 1924;27:119-43.

21. Miner RW. The pectral limb of Eryops and other primitive tetrapods. Bull Am Mus Nat Hist. 1925:51:145-308.

22. Burch SH. Complete forelimb myology of the basal theropod dinosaur Tawa hallae based on a novel robust muscle reconstruction method. J Anat. 2014; 225:271-97.

23. De Oliveira TV, Schultz CL. Functional morphology and biomechanics of the cynodont Trucidocynodon riograndensis from the Triassic of southern Brazil: pectoral girdle and forelimb. Acta Palaeontol Pol. 2016;61:377-86.

24. Molnar JL, Diogo R, Hutchinson JR, Pierce SE. Reconstructing pectoral appendicular muscle anatomy in fossil fish and tetrapods over the fins-tolimbs transition. Biol Rev. 2017;93:1077-107.

25. Howell AB. Morphogenesis of the shoulder architecture. Part III. Amphibia. Q Rev Biol. 1935;10:397-431.

26. Diogo R, Johnston P, Molnar JL, Esteve-Altava B. Characteristic tetrapod musculoskeletal limb phenotype emerged more than 400 MYA in basal lobe-finned fishes. Sci Rep. 2016;6:37592.

27. Miyake T, Kumamoto M, Iwata M, Sato R, Okabe M, Koie H, et al. The pectoral fin muscles of the coelacanth Latimeria chalumnae: functional and evolutionary implications for the fin-to-limb transition and subsequent evolution of tetrapods. Anat Rec. 2016;299:1203-23.

28. Diogo R, Abdala V. Comparative anatomy, homologies and evolution of the pectoral muscles of bony fish and tetrapods: a new insight. J Morphol. 2007;268:504-17.

29. Diogo R, Abdala V, Aziz MA, Lonergan N, Wood BA. From fish to modern humans - comparative anatomy, homologies and evolution of the pectoral and forelimb musculature. J Anat. 2009;214:694-716.

30. Walker JD, Geissman JW, Bowring SA, Babcok LE. Geological time scale v. 4. 0. Boulder: Geological Society of America; 2012. https://doi.org/10.1130/ 2012.CTS004R3C.

31. Shu DG, Luo HL, Conway-Morris S, Zhang XL, Hu SX, Chen L, et al. Lower Cambrian vertebrates from South China. Nature. 1999;402:42-6.

32. Shu DG, Morris SC, Han J, Zhang ZF, Yasui K, Janvier P, et al. Head and backbone of the early Cambrian vertebrate Haikouichthys. Nature. 2003;421:526-9.

33. Morris SC, Caron JB. A primitive fish from the Cambrian of North America. Nature. 2014;512:419-22.

34. Burrow CJ, Turner $\mathrm{S}$. A review of placoderm scales, and their significance in placoderm phylogeny. J Vert Paleontol. 1999;19:204-19. 
35. Janvier P. Facts and fancies about early fossil chordates and vertebrates. Nature. 2015;520:483-9.

36. Janvier $P$, Arsenault M, Desbiens $S$. Calcified cartilage in the paired fins of the osteostracan Escuminaspis laticeps (Traquair 1880), from the late Devonian of Miguasha (Quebec, Canada), with a consideration of the early evolution of the pectoral fin endoskeleton in vertebrates. J Vert Paleontol. 2004;24:773-9.

37. Zhu M, Yu XB, Choo B, Wang JQ, JL T. An antiarch placoderm shows that pelvic girdles arose at the root of jawed vertebrates. Biol Lett. 2012;8:453-6.

38. Zhu M, Zhao WJ, Jia LT, Lu J, Qiao T, Qu QM. The oldest articulated osteichthyan reveals mosaic gnathostome characters. Nature. 2009;458:469-74.

39. Coates MI, Ruta M, Friedman M. Ever since Owen: changing perspectives on the early evolution of tetrapods. Annu Rev Ecol Evol S. 2008;39:571-92.

40. Amemiya CT, Alfoldi J, Lee AP, Fan SH, Philippe H, MacCallum I, et al. The African coelacanth genome provides insights into tetrapod evolution. Nature. 2013:496:311-6.

41. Niedźwiedzki G, Szrek P, Narkiewicz K, Narkiewicz M, Ahlberg PE. Tetrapod trackways from the early middle Devonian period of Poland. Nature. 2010;463:43-8.

42. Friedman M, Brazeau MD. Sequences, stratigraphy and scenarios: what can we say about the fossil record of the earliest tetrapods? Proc R Soc B. 2011;278:432-9.

43. Ahlberg PE. Elginerpeton pancheni and the earliest tetrapod clade. Nature. 1995;373:420-5

44. Ahlberg PE, Clack JA, Luksevics E, Blom H, Zupins I. Ventastega curonica and the origin of tetrapod morphology. Nature. 2008;453:1199-204.

45. Andrews S. M., Westoll TS. The postcranial skeleton of Eusthenopteron foodi Whiteaves. Trans R Soc Edinburgh. 1970;68:207-329.

46. Coates MI. The Devonian tetrapod Acanthostega gunnari Jarvik: postcranial anatomy, basal tetrapod interrelationships and patterns of skeletal evolution. Trans R Soc Edinburgh Earth Sci. 1996;87:363-421.

47. Long JA, Young GC, Holland T, Senden TJ, Fitzgerald EMG. An exceptional Devonian fish from Australia sheds light on tetrapod origins. Nature. 2006:444:199-202.

48. Shubin NH, Daeschler EB, Jenkins FA. The pectoral fin of Tiktaalik roseae and the origin of the tetrapod limb. Nature. 2006;440:764-71.

49. Pierce SE, Clack JA, Hutchinson JR. Three-dimensional limb joint mobility in the early tetrapod Ichthyostega. Nature. 2012;486:523-6.

50. Shubin NH, Daeschler EB, Coates MI. The early evolution of the tetrapod humerus. Science. 2004;304:90-3.

51. Elinson RP. Muscle development in a biphasic animal: the frog. Dev Dyn. 2007;236:2444-53.

52. Martin BL, Harland RM. A novel role for $16 \times 1$ in Xenopus hypaxial myogenesis. Development. 2006;133:195-208.

53. Banfi S, Monti L, Acquati F, Tettamanti G, de Eguileor M, Grimaldi A. Muscle development and differentiation in the urodele Ambystoma mexicanum. Develop Growth Differ. 2012;54:489-502.

54. Byrnes EF. Experimental studies on the development of limb muscles in amphibia. J Morphol. 1898;14:105-40.

55. Chen HK. Development of the pectoral limb of Necturus maculosus. III Biol Monogr. 1935;14:1-71.

56. Chevallier A, Kieny M, Mauger A. Limb-somite relationship: origin of limb musculature. J Embryol Exp Morph. 1977;41:245-58.

57. Christ $B$, Jacob HJ, Jacob M. Experimental analysis of origin of wing musculature in avian embryos. Anat Embryol. 1977;150:171-86.

58. Wachtler F, Christ B, Jacob HJ. On the determination of mesodermal tissues in the avian embryonic wing bud. Anat Embryol. 1981;161:283-9.

59. Field HH. Die Vornierenkapsel, ventrale Musculatur und Extremitätenanlagen bei den Amphibien. Anat Anz. 1894;9:713-24.

60. Detwiler SR. Experiments on the development of the shoulder girdle and the anterior limb of Amblystoma punctatum. J Exp Zool. 1918;25:499-537.

61. Burke AC. Proximal elements in the vertebrate limb: evolutionary and developmental origin of the pectoral girdle. In: Hinchliffe JR, Hurle JM, Summerbell D, editors. Developmental patterning of the vertebrate limb. New York: Plenum Press; 1991. p. 385-94.

62. Wagner GP, Khan PA, Blanco MJ, Misof B, Liversage RA. Evolution of Hoxa-11 expression in amphibians: is the urodele autopodium an innovation? Am Zool. 1999;39:686-94.

63. Bickelmann C, Frota-Lima GN, Triepel SK, Kawaguchi A, Schneider I, Frobisch NB. Noncanonical Hox, Etv4, and Gli3 gene activities give insight into unique limb patterning in salamanders. J Exp Zool B (MDE). 2018;330:138-47.

64. Shubin $\mathrm{NH}$, Alberch P. A morphogenetic approach to the origin and basic organization of the tetrapod limb. Evol Biol. 1986;20:319-87.
65. Fröbisch NB, Shubin NH. Salamander limb development: integrating genes, morphology, and fossils. Dev Dyn. 2011;240:1087-99.

66. Diogo R, Tanaka EM. Development of fore- and hindlimb muscles in GFPtransgenic axolotls: morphogenesis, the tetrapod bauplan, and new insights on the forelimb-hindlimb enigma. J Exp Zool B (MDE). 2014;322:106-27.

67. Gardiner DM, Carlson MRJ, Roy S. Towards a functional analysis of limb regeneration. Semin Cell Dev Biol. 1999;10:385-93.

68. Galis F, Wagner GP, Jockusch EL. Why is limb regeneration possible in amphibians but not in reptiles, birds, and mammals? Evol Dev. 2003;5:208-20.

69. Stocum DL, Cameron JA. Looking proximally and distally: 100 years of limb regeneration and beyond. Dev Dyn. 2011;40:943-68.

70. Ruta M, Coates MI. Dates, nodes and character conflict: addressing the lissamphibian origin problem. J Syst Palaeontol. 2007;5:69-122.

71. Pardo JD, Small BJ, Huttenlocker AK. Stem caecilian from the Triassic of Colorado sheds light on the origins of Lissamphibia. Proc Natl Acas Sci. 2017;114:E5389-95. https://doi.org/10.1073/pnas.1706752114.

72. Pardo JD, Szostakiwskyj M, Ahlberg PE, Anderson JS. Hidden morphological diversity among early tetrapods. Nature. 2017;546:642-5.

73. Marjanović D, Laurin M. The origin(s) of extant amphibians: a review with emphasis on the "lepospondyl hypothesis". Geodiversitas. 2013;35:207-72.

74. Schoch RR. Evolution of life cycles in early amphibians. Annu Rev Earth PI Sc. 2009;37:135-62.

75. Schoch RR, Witzmann F. Bystrow's paradox: gills, fossils, and the fish-totetrapod transition. Acta Zool-Stockholm. 2011;92:251-65.

76. Schoch RR. Amphibian evolution: the life of early land vertebrates. Chihester: Wiley; 2014.

77. Laudet $\mathrm{V}$. The origins and evolution of vertebrate metamorphosis. Curr Biol. 2011;21:R726-37.

78. Witzmann F, Pfretzschner HU. Larval ontogeny of Micromelerpeton credneri (Temnospondyli, Dissorophoidea). J Vert Paleontol. 2003;23:750-68.

79. Schoch RR, Fröbisch NB. Metamorphosis and neoteny: alternative pathways in an extinct amphibian clade. Evolution. 2006;60:1467-75.

80. Fröbisch NB, Olori JC, Schoch RR, Witzmann F. Amphibian development in the fossil record. Semin Cell Dev Biol. 2010;21:424-31.

81. Carroll RL. Developmental aspects of lepospondyl vertebrae in Paleozoic tetrapods. Historical Biol. 1989;3:1-25.

82. Cote S, Carroll R, Cloutier R, Bar-Sagi L. Vertebral development in the Devonian sarcopterygian fish Eusthenopteron foordi and the polarity of vertebral evolution in non-amniote tetrapods. J Vert Paleontol. 2002;22:487-502.

83. Fröbisch NB, Carroll RL, Schoch RR. Limb ossification in the Paleozoic branchiosaurid Apateon (Temnospondyli) and the early evolution of preaxial dominance in tetrapod limb development. Evol Dev. 2007;9:69-75.

84. Fröbisch NB, Bickelmann C, Olori JC, Witzmann F. Deep-time evolution of regeneration and preaxial polarity in tetrapod limb development. Nature. 2015;527:231-4.

85. Sandoval-Guzmán T, Wang H, Khattak S, Schuez M, Roensch K, Nacu E, Tazaki A, Joven A, Tanaka EM, Simon A. Fundamental differences in dedifferentiation and stem cell recruitment during skeletal muscle regeneration in two salamander species. Cell Stem Cell. 2014;14:174-87.

86. Tanaka HV, Ng NCY, Yu ZY, Casco-Robles MM, Maruo F, Tsonis PA, Chiba C. A developmentally regulated switch from stem cells to dedifferentiation for limb muscle regeneration in newts. Nat Commun. 2016;7:11069.

87. Nogueira AF, Costa CM, Lorena J, Moreira RN, Frota-Lima GN, Furtado C, Robinson M, Amemiya CT, Darnet S, Schneider I. Tetrapod limb and sarcopterygian fin regeneration share a core genetic programme. Nat Commun. 2016;7:13364.

88. Fürbringer M. Untersuchungen zur Morphologie und Systematik der Vögel: zugleich ein Beitrag zur Anatomie der Stütz- und Bewegungsorgane. Amsterdam: Van Holkema; 1888.

89. van der Horst Cl. Spinalnerven. In: Bolk L, Göppert E, Kallius E, Lubosch W, editors. Handbuch der vergleichenden Anatomie der Wirbeltiere, Bd 2. Berlin: Urban und Schwarzenberg; 1934. p. 505-40.

90. Howell AB. Morphogenesis of the shoulder architecture. Part IV. Reptilia. Q Rev Biol. 1936;11:183-208.

91. Howell AB. Morphogenesis of the shoulder architecture. Part V. Monotremata. Q Rev Biol. 1937;12:191-205.

92. Howell AB. Morphogenesis of the shoulder architecture. Part VI. Therian mammalia. Q Rev Biol. 1937;12:440-63.

93. Howell AB. Morphogenesis of the shoulder architecture: Aves. Auk. 1937;54:364-75. 
94. Fürbringer M. Über die spino-occipitalen Nerven der Selachier und Holocephalen und ihre vergleichende Morphologie. In: Festschrift zum siebenzigsten geburtstag von Carl Gegenbaur, Bd 3. Leipzig: Verlag von Wilhelm Engelmann; 1897. p. 349-788.

95. Braus H. Die Muskeln und Nerven der Ceratodusflosse. Ein Beitrag zur vergleichenden Morphologie der freien Gliedmaasse bei niederen Fischen und zur Archipterygiumtheorie. Denkschriften der MedicinischNaturwissenschaftlichen Gesellschaft zu Jena. 1901:4:137-300.

96. Goodrich ES. On the segmental structure of the motor nerve-plexus. Anat Anz. 1910;36:109-13.

97. Howell AB. Morphogenesis of the shoulder architecture. Part II. Pisces. Q Rev Biol. 1933:8:434-56.

98. Ma LH, Gilland E, Bass AH, Baker R. Ancestry of motor innervation to pectoral fin and forelimb. Nat Commun. 2010;1:49.

99. Semon R. Die Entwickelung der paarigen Flossen des Ceratodus forsteri. Denkschriften der Medicinisch-Naturwissenschaftlichen Gesellschaft zu Jena. 1898:4:59-111.

100. Mollier S. Die paarigen Extremitäten der Wirbeltiere. III. Die Entwickelung der paarigen Flossen des Stöhrs. Anat Hefte. 1897;8:1-74

101. Millot J, Anthony J. Anatomie de Latimeria chalumnae. Tome I. Squelette, muscles et formations de soutien. Paris: Éditions du Centre national de la recherche scientifique; 1958.

102. Millot J, Anthony J. Anatomie de Latimeria chalumnae. Tome II. Système nerveux et organs des Sens. Paris: Éditions du Centre national de la recherche scientifique; 1965.

103. Sieglbauer F. Zur Anatomie der Schildkrötenextremität. Arch Anat Physiol. Anat Abt. 1909;32(suppl):183-280.

104. Miller RA, Detwiler SR. Comparative studies upon the origin and development of the brachial plexus. Anat Rec. 1936;65:273-92.

105. Yasuda M. Comparative and topographical anatomy of the fowl. III. On the nervous supply of the thoracic limb in the fowl. Jpn J Vet Sci. 1960;22:89-101.

106. Roncali $\mathrm{L}$. The brachial plexus and the wing nerve pattern during early developmental phases in chicken embryos. Monit Zool Ital. 1970;4:81-98.

107. Koizumi M, Sakai T. On the morphology of the brachial plexus of the platypus (Ornithorhynchus anatinus) and the echidna (Tachyglossus aculeatus). J Anat. 1997:190:447-55.

108. Meers MB. Crocodylian forelimb musculature and its relevance to archosauria. Anat Rec. 2003:274A:891-916.

109. Kerr ET. Brachial plexus of nerves in man, the variations in its formation and branches. Am J Anat. 1918;23:285-395.

110. Hirasawa T, Kuratani S. A new scenario of the evolutionary derivation of the mammalian diaphragm from shoulder muscles. J Anat. 2013;222:504-17.

111. Fischel A. Zur entwicklung der ventralen Rumpf- und der Extremitätenmuskulatur der Vögel und Säugethiere. Morphol Jahrb. 1895;23:544-61.

112. Corning HK. Über die Entwicklung der Kopf- und Extremitätenmuskulatur bei Reptilien. Morphol Jahrb. 1900;28:28-104.

113. Lewis WH. The development of the arm in man. Am J Anat. 1902:1:145-83.

114. Sewertzoff AN. Studien über die Entwickelung der Muskeln, Nerven und des Skeletts der Extremitäten der niederen Tetrapoda. Bull Soc Imp Nat Moscou. 1907;21:1-430

115. Gasser SM. Visualizing chromatin dynamics in interphase nuclei. Science. 2002;296:1412-6.

116. Romer AS. The development of tetrapod limb musculature - the shoulder region of Lacerta. J Morphol. 1944;74:1-41.

117. Cheng CC. The development of the shoulder region of the opossum Didelphys virginiana with special reference to the musculature. J Morphol. 1955;97:415-71.

118. Romer AS, Parsons TS. The vertebrate body. 5th ed. Philadelphia: W. B. Saunders; 1977

119. Valasek $P$, Theis S, DeLaurier A, Hinits Y, Luke GN, Otto AM, et al. Cellular and molecular investigations into the development of the pectoral girdle. Dev Biol. 2011;357:108-16.

120. Saberi M, Pu Q, Valasek P, Norizadeh-Abbariki T, Patel K, Huang R. The hypaxial origin of the epaxially located rhomboid muscles. Ann Anat. 2017:214:15-20.

121. Lewis WH. The development of the muscular system. In: Keibel F, Mall FP, editors. Manual of human embryology, vol. 1. Philadelphia: J. B. Lippincott; 1910. p. 454-522.

122. Mollier S. Die paarigen Extremitäten der Wirbeltiere. I. Das Ichthyopterygium. Anat Hefte. 1893:3:1-160.

123. Neyt C, Jagla K, Thisse C, Thisse B, Haines L, Currie PD. Evolutionary origins of vertebrate appendicular muscle. Nature. 2000;408:82-6.
124. Galis F. Evolutionary history of vertebrate appendicular muscle. Bioessays. 2001;23:383-7.

125. Cole NJ, Currie PD. Insights from sharks: evolutionary and developmental models of fin development. Dev Dyn. 2007;236:2421-31.

126. Cole NJ, Hall TE, Don EK, Berger S, Boisvert CA, Neyt C, et al. Development and evolution of the muscles of the pelvic fin. PLOS Biol. 2011:9:e1001168.

127. Goodrich ES. Notes on the development, structure, and origin of the median and paired fins of fish. Q J Microsc Sci. 1906;50:333-76.

128. Müller E. Untersuchungen über die Anatomie und Entwicklung des peripheren Nervensystems bei den Selachiern. Arc mikr Anat. 1913;81:325-76.

129. Okamoto E, Kusakabe R, Kuraku S, Hyodo S, Robert-Moreno A, Onimaru K, et al. Migratory appendicular muscles precursor cells in the common ancestor to all vertebrates. Nat Ecol Evol. 2017:1:1731-6.

130. Corning HK. Über die ventralen Urwirbelknospen in der Brustflosse der Teleostier. Morphol Jahrb. 1895;22:79-98.

131. Salensky W. Entwicklungsgeschichte des Ichthyopterygiums. In: Proc fourth Internat congress Zool; 1899. p. 177-83.

132. Dietrich S, Schubert FR, Healy C, Sharpe PT, Lumsden A. Specification of the hypaxial musculature. Development. 1998;125:2235-49.

133. Dietrich S. Regulation of hypaxial muscle development. Cell Tissue Res. 1999;296:175-82.

134. Dietrich S, Abou-Rebyeh F, Brohmann H, Bladt F, Sonnenberg-Riethmacher E, Yamaai T, et al. The role of SF/HGF and c-met in the development of skeletal muscle. Development. 1999;126:1621-9.

135. Winslow BB, Takimoto-Kimura R, Burke AC. Global patterning of the vertebrate mesoderm. Dev Dyn. 2007;236:2371-81.

136. Kusakabe R, Kuratani S. Evolution and developmental patterning of the vertebrate skeletal muscles: perspectives from the lamprey. Dev Dyn. 2005;234:824-34.

137. van Bemmelen JF. Über die Herkunft der Extremitäten- und Zungenmuskulatur bei Eidechsen. Anat Anz. 1889;4:240-55.

138. Buckingham M, Bajard L, Chang T, Daubas P, Hadchouel J, Meilhac S, et al. The formation of skeletal muscle: from somite to limb. J Anat. 2003;202:59-68.

139. Vasyutina $E$, Birchmeier $C$. The development of migrating muscle precursor cells. Anat Embryol. 2006;211:\$37-41.

140. Mok GF, Sweetman D. Many routes to the same destination: lessons from skeletal muscle development. Reproduction. 2011;141:301-12

141. Buckingham M, Rigby PW. Gene regulatory networks and transcriptional mechanisms that control myogenesis. Dev Cell. 2014;28:225-38.

142. Tremblay P, Dietrich S, Mericskay M, Schubert FR, Li ZL, Paulin D. A crucial role for Pax3 in the development of the hypaxial musculature and the longrange migration of muscle precursors. Dev Biol. 1998;203:49-61.

143. Brohmann $H$, Jagla $K$, Birchmeier $C$. The role of $L b x 1$ in migration of muscle precursor cells. Development. 2000;127:437-45.

144. Gross MK, Moran-Rivard L, Velasquez T, Nakatsu MN, Jagla K, Goulding M. $L b \times 1$ is required for muscle precursor migration along a lateral pathway into the limb. Development. 2000;127:413-24.

145. Mennerich D, Braun T. Activation of myogenesis by the homeobox gene Lbx1 requires cell proliferation. EMBO J. 2001:20:7174-83.

146. Bladt F, Riethmacher D, Isenmann S, Aguzzi A, Birchmeier C. Essential role for the c-met receptor in the migration of myogenic precursor cells into the limb bud. Nature. 1995;376:768-71.

147. Scaal M, Bonafede A, Dathe V, Sachs M, Cann G, Christ B, Brand-Saberi B. SF/ HGF is a mediator between limb patterning and muscle development. Development. 1999:126:4885-93.

148. Ochi H, Westerfield M. Lbx2 regulates formation of myofibrils. BMC Dev Biol. 2009;9:13.

149. Sabo MC, Nath K, Elinson RP. Lbx1 expression and frog limb development. Dev Genes Evol. 2009;219:609-12.

150. Wotton KR, Schubert FR, Dietrich S. Hypaxial muscle: controversial classification and controversial data? In: Brand-Saberi B, editor. Vertebrate myogenesis. Heidelberg: Springer; 2015. p. 25-48.

151. Gegenbaur C. Zur Phylogenese der Zunge. Morphol Jahrb. 1894:21:1-18.

152. Mackenzie S, Walsh FS, Graham A. Migration of hypoglossal myoblast precursors. Dev Dyn. 1998;213:349-58.

153. Lours-Calet C, Alvares LE, El-Hanfy AS, Gandesha S, Walters EH, Sobreira DR, et al. Evolutionarily conserved morphogenetic movements at the vertebrate head-trunk interface coordinate the transport and assembly of hypopharyngeal structures. Dev Biol. 2014;390:231-46.

154. True JR, Haag ES. Developmental system drift and flexibility in evolutionary trajectories. Evol Dev. 2001;3:109-19. 
155. Nowoshilow S, Schloissnig S, Fei JF, Dahl A, Pang AWC, Pippel M, et al. The axolotl genome and the evolution of key tissue formation regulators. Nature. 2018;554:50-5.

156. Alvares LE, Schubert FR, Thorpe C, Mootoosamy RC, Cheng L, Parkyn G, et al. Intrinsic, Hox-dependent cues determine the fate of skeletal muscle precursors. Dev Cell. 2003;5:379-90.

157. Christ B, Epperlein HH, Flöel H, Wilting J. The somite-muscle relationship in the avian embryo. In: Hinchliffe JR, Hurle JM, Summerbell D, editors. Developmental patterning of the vertebrate limb. New York: Plenum Press; 1991. p. 265-71.

158. Charras G, Sahai E. Physical influences of the extracellular environment on cell migration. Nat Rev Mol Cell Bio. 2014;15:813-24.

159. Brand-Saberi B, Krenn V. Observations concerning the control of directed myogenic cell migration. In: Hinchliffe JR, Hurle JM, Summerbell D, editors. Developmental patterning of the vertebrate limb. New York: Plenum Press; 1991. p. 273-84

160. Kardon G, Campbell JK, Tabin CJ. Local extrinsic signals determine muscle and endothelial cell fate and patterning in the vertebrate limb. Dev Cell. 2002;3:533-45

161. Yvernogeau L, Auda-Boucher G, Fontaine-Perus J. Limb bud colonization by somite-derived angioblasts is a crucial step for myoblast emigration. Development. 2012:139:277-87.

162. Mayeuf-Louchart A, Lagha M, Danckaert A, Rocancourt D, Relaix F, Vincent $\mathrm{SD}$, Buckingham $\mathrm{M}$. Notch regulation of myogenic versus endothelial fates of cells that migrate from the somite to the limb. Proc Natl Acad Sci. 2014; 111:8844-9.

163. Mayeuf-Louchart A, Montarras D, Bodin C, Kume T, Vincent SD, Buckingham $M$. Endothelial cell specification in the somite is compromised in Pax3positive progenitors of Foxc1/2 conditional mutants, with loss of forelimb myogenesis. Development. 2016;143:872-9.

164. Huang RJ, Zhi QX, Christ B. The relationship between limb muscle and endothelial cells migrating from single somite. Anat Embryol. 2003;206:283-9.

165. Duprez D. Signals regulating muscle formation in the limb during embryonic development. Int J Dev Biol. 2002;46:915-25.

166. Murphy M, Kardon G. Origin of vertebrate limb muscle: the role of progenitor and myoblast populations. In: Pavlath GK, editor. Current topics in developmental biology, Vol 96: Myogenesis. San Diego: Elsevier; 2011. p. 1-32.

167. Lance-Jones C. The somitic level of origin of embryonic chick hindlimb muscles. Dev Biol. 1988;126:394-407.

168. Ordahl CP, Le Douarin NM. Two myogenic lineages within the developing somite. Development. 1992;114:339-53.

169. Beresford B. Brachial muscles in the chick embryo: the fate of individual somites. J Embryol Exp Morph. 1983;77:99-116.

170. Zhi Q, Huang R, Christ B, Brand-Saberi B. Participation of individual brachial somites in skeletal muscles of the avian distal wing. Anat Embryol. 1996;194:327-39.

171. Wyngaarden LA, Vogeli KM, Ciruna BG, Wells M, Hadjantonakis AK, Hopyan S. Oriented cell motility and division underlie early limb bud morphogenesis. Development. 2010;137:2551-8.

172. Mao QY, Stinnett HK, Ho RK. Asymmetric cell convergence-driven zebrafish fin bud initiation and pre-pattern requires Tbx5a control of a mesenchymal Fgf signal. Development. 2015;142:4329-39.

173. Chal J, Pourquié O. Making muscle: skeletal myogenesis in vivo and in vitro. Development. 2017;144:2104-22

174. Harrison RG. Experiments on the development of the fore limb of Amblystoma, a self-differentiating equipotential system. J Exp Zool. 1918;25:413-61.

175. Shellswell GB, Bailey AJ, Duance VC, Restall DJ. Has collagen a role in muscle pattern formation in the developing chick wing? 1. An immunofluorescence study. J Embryol Exp Morph. 1980;60:245-54.

176. Chevallier A, Kieny M. On the role of the connective tissue in the patterning of the chick limb musculature. Roux Arch Dev Biol. 1982;191:277-80.

177. Grim M. Control of muscle morphogenesis and endplate pattern in limb muscles of avian chimeras. In: Hinchliffe JR, Hurle JM, Summerbell D, editors. Developmental patterning of the vertebrate limb. New York: Plenum Press; 1991. p. 293-7.

178. Kardon G, Harfe BD, Tabin CJ. A Tcf4-positive mesodermal population provides a prepattern for vertebrate limb muscle patterning. Dev Cell. 2003:5:937-44.

179. Hasson P. "Soft" tissue patterning: muscles and tendons of the limb take their form. Dev Dyn. 2011;240:1100-7.

180. Mathew SJ, Hansen JM, Merrell AJ, Murphy MM, Lawson JA, Hutcheson DA, et al. Connective tissue fibroblasts and Tcf4 regulate myogenesis. Development. 2011;138:371-84.
181. Nassari S, Duprez D, Fournier-Thibault C. Non-myogenic contribution to muscle development and homeostasis: the role of connective tissues. Front Cell Dev Biol. 2017;5:22.

182. Vallecillo-García P, Orgeur M, Vom Hofe-Schneider S, Stumm J, Kappert V, Ibrahim DM, et al. Odd skipped-related 1 identifies a population of embryonic fibro-adipogenic progenitors regulating myogenesis during limb development. Nat Commun. 2017:8:1218.

183. Geetha-Loganathan P, Nimmagadda S, Pröls F, Patel K, Scaal MT, Huang RJ, Christ B. Ectodermal Wnt-6 promotes Myf5-dependent avian limb myogenesis. Dev Biol. 2005;288:221-33.

184. Swartz ME, Eberhart J, Pasquale EB, Krull CE. EphA4/ephrin-A5 interactions in muscle precursor cell migration in the avian forelimb. Development. 2001; 128:4669-80.

185. Vasyutina E, Stebler J, Brand-Saberi B, Schulz S, Raz E, Birchmeier C. CXCR4 and Gab1 cooperate to control the development of migrating muscle progenitor cells. Genes Dev. 2005;19:2187-98.

186. Masyuk M, Abduelmula A, Morosan-Puopolo G, Ödemis V, Rehimi R, Khalida $\mathrm{N}$, et al. Retrograde migration of pectoral girdle muscle precursors depends on CXCR4/SDF-1 signaling. Histochem Cell Biol. 2014;142:473-88.

187. Masyuk M, Brand-Saberi B. Recruitment of skeletal muscle progenitors to secondary sites: a role for CXCR4/SDF-1 signalling in skeletal muscle development. In: Brand-Saberi B, editor. Vertebrate myogenesis. Heidelberg: Springer; 2015. p. 1-23.

188. Pu Q, Huang R, Brand-Saberi B. Development of the shoulder girdle musculature. Dev Dyn. 2016;245:342-50.

189. Benjamin M. The fascia of the limbs and back: a review. J Anat. 2009;214:1-18.

190. Mrázková O. Blood vessel ontogeny in upper extremity of man as related to developing muscles. Acta Univ Carol Med Monogr. 1986;115:1-114

191. Tozer S, Bonnin MA, Relaix F, Di Savino S, García-Villalba P, Coumailleau P, Duprez D. Involvement of vessels and PDGFB in muscle splitting during chick limb development. Development. 2007;134:2579-91.

192. Yano T, Abe G, Yokoyama H, Kawakami K, Tamura K. Mechanism of pectoral fin outgrowth in zebrafish development. Development. 2012;139:2916-25.

193. Ambler CA, Nowicki JL, Burke AC, Bautch VL. Assembly of trunk and limb blood vessels involves extensive migration and vasculogenesis of somitederived angioblasts. Dev Biol. 2001;234:352-64.

194. Müller E. Beiträge zur Morphologie des Gefässsystems. I. Die Armarterien der menschen. Anat Hefte. 1903:22:377-575.

195. Adachi B. Das Arteriensystem der Japaner. Band I. Kyoto: Verlag der Kaiserlich-Japanischen Universität zu Kyoto; 1928.

196. Wankoff W. Uber einige Gesetzmäßigkeiten bei der Variabilität der Arterien der oberen Extremität. Anat Anz. 1962;111:216-40.

197. Rodríguez-Niedenführ M, Vázquez T, Nearn L, Ferreira B, Parkin I, Sañudo JR. Variations of the arterial pattern in the upper limb revisited: a morphological and statistical study, with a review of the literature. J Anat. 2001;199:547-66.

198. Kachlik D, Konarik M, Riedlova J, Baca V. Brachiomedian artery (arteria brachiomediana) revisited: a comprehensive review. Bosnian J Basic Med. 2016;16:91-101.

199. Weinstein BM. What guides early embryonic blood vessel formation? Dev Dyn. 1999;215:2-11.

200. Woollard HH. The development of the principal arterial stems in the forelimb of the pig. Contrib Embryol. 1921:14:139-54

201. Evans HM. On the earliest blood-vessels in the anterior limb buds of birds and their relation to the primary subclavian artery. Am J Anat. 1909:9:281-319.

202. Seichert V, Rychter Z. Vascularization of the developing anterior limb of the chick embryo. I. Sinus marginalis, its development, fate and importance. Folia Morphol (Praha). 1971;19:367-77.

203. Seichert V, Rychter Z. Vascularization of developing anterior lamb of the chick embryo. II. Differentiation of vascular bed and its significance for the location of morphogenetic processes inside the limb bud. Folia Morphol (Praha). 1972;20:352-61.

204. Carte A, Macalister A. On the anatomy of Balaenoptera rostrata. Philos Trans R Soc Lond. 1868;158:201-61.

205. Murie J. On the organization of the Caaing whale, Globiocephalus melas. Trans Zool Soc London. 1874:8:235-302.

206. Strickler TL. Myology of shoulder of Pontoporia blainvillei, including a review of literature on shoulder morphology in Cetacea. Am J Anat. 1978;152:419-31.

207. Cooper LN, Dawson SD, Reidenberg JS, Berta A. Neuromuscular anatomy and evolution of the cetacean forelimb. Anat Rec. 2007;290:1121-37. 
208. Sanchez JA, Berta A. Comparative anatomy and evolution of the odontocete forelimb. Mar Mammal Sci. 2010;26:140-60.

209. Zuckerkandl E. Zur Anatomie Entwicklungsgeschichte des Vorderarmes. I. Teil. Anat Hefte. 1894;4:1-98.

210. Müller E. Beiträge zur Morphologie des Gefässsystems. II. Die Armarterien der Säugetiere. Anat Hefte. 1905;27:71-243.

211. Louw GJ. Functional anatomy of the penguin flipper. J S Afr Vet Assoc. 1992;63:113-20.

212. Millot J, Anthony J, Robineau D. Anatomie de Latimeria chalumnae. Tome III. Appareil digestif, appareil respiratoire, appareil urogénital, glandes endocrines, appareil circulatoire, téguments, ecailles, et conclusions générales. Paris: Éditions du Centre national de la recherche scientifique; 1978.

213. Logan M, Tabin CJ. Role of Pitx1 upstream of Tbx4 in specification of hindlimb identity. Science. 1999;283:1736-9.

214. Takeuchi JK, Koshiba-Takeuchi K, Matsumoto K, Vogel-Hopker A, NaitohMatsuo M, Ogura K, et al. Tbx5 and Tbx4 genes determine the wing/leg identity of limb buds. Nature. 1999:398:810-4.

215. DeLaurier A, Schweitzer R, Logan M. Pitx1 determines the morphology of muscle, tendon, and bones of the hindlimb. Dev Biol. 2006;299:22-34.

216. Duboc $V$, Logan MPO. Regulation of limb bud initiation and limb-type morphology. Dev Dyn. 2011;240:1017-27.

217. Spielmann M, Brancati F, Krawitz PM, Robinson PN, Ibrahim DM, Franke M, et al. Homeotic arm-to-leg transformation associated with genomic rearrangements at the PITX1 locus. Am J Hum Genet. 2012;91:629-35.

218. Čihák R. Phylogenetically ancient pattern in ontogenesis of limb muscles. In: Hinchliffe JR, Hurle JM, Summerbell D, editors. Developmental patterning of the vertebrate limb. New York: Plenum Press; 1991. p. 355-63.

219. Lipton BH, Konigsberg IR. A fine-structural analysis of fusion of myogenic cells. J Cell Biol. 1972;53:348-64.

220. Deries M, Thorsteinsdóttir S. Axial and limb muscle development: dialogue with the neighbourhood. Cell Mol Life Sci. 2016;73:4415-31.

221. Comai G, Tajbakhsh S. Molecular and cellular regulation of skeletal myogenesis. Curr Top Dev Biol. 2014;110:1-73.

222. Stark DA, Karvas RM, Siegel AL, Cornelison DDW. Eph/ephrin interactions modulate muscle satellite cell motility and patterning. Development. 2011;138:5279-89.

223. Murphy MM, Lawson JA, Mathew SJ, Hutcheson DA, Kardon G. Satellite cells, connective tissue fibroblasts and their interactions are crucial for muscle regeneration. Development. 2011;138:3625-37.

224. Watanabe S, Kondo S, Hayasaka M, Hanaoka K. Functional analysis of homeodomain-containing transcription factor Lbx1 in satellite cells of mouse skeletal muscle. J Cell Sci. 2007;120:4178-87.

225. Tank PW, Connelly TG, Bookstein FL. Cellular behavior in the anteroposterior axis of the regenerating forelimb of the axolotl, Ambystoma mexicanum. Dev Biol. 1985;109:215-23.

226. Wang $H$, Simon A. Skeletal muscle dedifferentiation during salamander limb regeneration. Curr Opin Genet Dev. 2016;40:108-12.

227. Summers AP, Koob TJ. The evolution of tendon - morphology and material properties. Comp Biochem Physiol A Mol Integr Physiol. 2002;133:1159-70.

228. Mouw JK, Ou GQ, Weaver VM. Extracellular matrix assembly: a multiscale deconstruction. Nat Rev Mol Cell Bio. 2014;15:771-85.

229. Tozer S, Duprez D. Tendon and ligament: development, repair and disease. Birth Defects Res C. 2005;75:226-36.

230. Cooper RR, Misol S. Tendon and ligament insertion: a light and electron microscopic study. J Bone Joint Surg Am. 1970;52-A:1-20.

231. Blitz E, Sharir A, Akiyama H, Zelzer E. Tendon-bone attachment unit is formed modularly by a distinct pool of Scx- and Sox9-positive progenitors. Development. 2013;140:2680-90.

232. Sugimoto $Y$, Takimoto A, Akiyama $H$, Kist $R$, Scherer $G$, Nakamura $T$, et al Scx+/Sox9+ progenitors contribute to the establishment of the junction between cartilage and tendon/ligament. Development. 2013;140:2280-8.

233. Zelzer $\mathrm{E}_{t}$ Blitz $\mathrm{E}$, Killian ML, Thomopoulos S. Tendon-to-bone attachment: from development to maturity. Birth Defects Res C. 2014;102:101-12.

234. Hasson P, DeLaurier A, Bennett M, Grigorieva E, Naiche LA, Papaioannou VE, et al. Tbx4 and Tbx5 acting in connective tissue are required for limb muscle and tendon patterning. Dev Cell. 2010;18:148-56.

235. Caplan Al. Extracellular matrix and muscle formation. In: Hinchliffe JR, Hurle JM, Summerbell D, editors. Developmental patterning of the vertebrate limb. New York: Plenum Press; 1991. p. 285-92.

236. Kardon G. Muscle and tendon morphogenesis in the avian hind limb. Development. 1998;125:4019-32.
237. Edom-Vovard F, Schuler B, Bonnin MA, Teillet MA, Duprez D. Fgf4 positively regulates scleraxis and tenascin expression in chick limb tendons. Dev Biol. 2002;247:351-66.

238. Edom-Vovard F, Duprez D. Signals regulating tendon formation during chick embryonic development. Dev Dyn. 2004;229:449-57.

239. Eloy-Trinquet S, Wang H, Edom-Vovard F, Duprez D. Fgf signaling components are associated with muscles and tendons during limb development. Dev Dyn. 2009;238:1195-206.

240. Rodriguez-Guzman M, Montero JA, Santesteban E, Gañan Y, Macias D, Hurle JM. Tendon-muscle crosstalk controls muscle bellies morphogenesis, which is mediated by cell death and retinoic acid signaling. Dev Biol. 2007;302:267-80.

241. Huang AH, Riordan TJ, Pryce B, Weibel JL, Watson SS, Long F, et al. Musculoskeletal integration at the wrist underlies the modular development of limb tendons. Development. 2015;142:2431-41.

242. Huang AH, Riordan TJ, Wang LY, Eyal S, Zelzer E, Brigande JV, Schweitzer R. Repositioning forelimb superficialis muscles: tendon attachment and muscle activity enable active relocation of functional myofibers. Dev Cell. 2013;26:544-51.

243. Cserjesi P, Brown D, Ligon KL, Lyons GE, Copeland NG, Gilbert DJ, et al. Scleraxis: a basic helix-loop-helix protein that prefigures skeletal formation during mouse embryogenesis. Development. 1995;121:1099-110.

244. Schweitzer R, Chyung JH, Murtaugh LC, Brent AE, Rosen V, Olson EN, et al. Analysis of the tendon cell fate using Scleraxis, a specific marker for tendons and ligaments. Development. 2001;128:3855-66.

245. Murchison ND, Price BA, Conner DA, Keene DR, Olson EN, Tabin CJ, Schweitzer R. Regulation of tendon differentiation by scleraxis distinguishes force-transmitting tendons from muscle-anchoring tendons. Development. 2007;134:2697-708.

246. Pryce BA, Brent AE, Murchison ND, Tabin CJ, Schweitzer R. Generation of transgenic tendon reporters, SCXGFP and SCXAP, using regulatory elements of the scleraxis gene. Dev Dyn. 2007;236:1677-82.

247. Chen JW, Galloway JL. The development of zebrafish tendon and ligament progenitors. Development. 2014;141:2035-45.

248. Li YH, Ramcharan M, Zhou ZP, Leong DJ, Akinbiyi T, Majeska RJ, Sun HB. The role of scleraxis in fate determination of mesenchymal stem cells for tenocyte differentiation. Sci Rep. 2015;5:13149.

249. Pryce BA, Watson SS, Murchison ND, Staverosky JA, Dünker N, Schweitzer R. Recruitment and maintenance of tendon progenitors by TGFbeta signaling are essential for tendon formation. Development. 2009;136:1351-61.

250. Nassari S, Blavet C, Bonnin MA, Stricker S, Duprez D, Fournier-Thibault C. The chemokines CXCL12 and CXCL14 differentially regulate connective tissue markers during limb development. Sci Rep. 2017;7:17279.

251. Wright DE, Snider WD. Focal expression of glial cell line-derived neurotrophic factor in developing mouse limb bud. Cell Tissue Res. 1996;286:209-17.

252. Haase G, Dessaud E, Garcès A, de Bovis B, Birling MC, Filippi P, et al. GDNF acts through $\mathrm{PEA} 3$ to regulate cell body positioning and muscle innervation of specific motor neuron pools. Neuron. 2002;35:893-905.

253. Kramer ER, Knott L, Su FY, Dessaud E, Krull CE, Helmbacher F, Klein R. Cooperation between GDNF/ret and ephrinA/EphA4 signals for motor-axon pathway selection in the limb. Neuron. 2006;50:35-47.

254. Bardeen CR. Development and variation of the nerves and the musculature of the inferior extremity and of the neighboring regions of the trunk in man. Am J Anat. 1907;6:259-390.

255. Harrison RG. Experiments in transplanting limbs and their bearing upon the problems of the development of nerves. J Exp Zool. 1907;4:239-81.

256. Hurren B, Collins JJP, Duxson MJ, Deries M. First neuromuscular contact correlates with onset of primary myogenesis in rat and mouse limb muscles. PLoS One. 2015;10:e0133811.

257. Hollyday M. Chick wing innervation. I. Time course of innervation and early differentiation of the peripheral nerve pattern. J Comp Neurol. 1995;357: 242-53.

258. Wang G, Scott SA. The "waiting period" of sensory and motor axons in early chick hindlimb: its role in axon pathfinding and neuronal maturation. J Neurosci. 2000;20:5358-66.

259. Dasen JS, Tice BC, Brenner-Morton S, Jessell TM. A Hox regulatory network establishes motor neuron pool identity and target-muscle connectivity. Cell. 2005;123:477-91.

260. Dasen JS, Jessell TM. Hox networks and the origins of motor neuron diversity. Curr Top Dev Biol. 2009;88:169-200.

261. Philippidou P, Walsh CM, Aubin J, Jeannotte L, Dasen JS. Sustained Hox5 gene activity is required for respiratory motor neuron development. Nat Neurosci. 2012;15:1636-44. 
262. Lacombe J, Hanley O, Jung H, Philippidou P, Surmeli G, Grinstein J, Dasen JS. Genetic and functional modularity of Hox activities in the specification of limb-innervating motor neurons. PLoS Genet. 2013;9:e1003184.

263. Catela C, Shin MM, Dasen JS. Assembly and function of spinal circuits for motor control. Annu Rev Cell Dev Bi. 2015;31:669-98.

264. Jung H, Baek M, D'Elia KP, Boisvert C, Currie PD, Tay BH, et al. The ancient origins of neural substrates for land walking. Cell. 2018;172:667-82.

265. Keynes RJ, Stirling RV, Stern CD, Summerbell D. The specificity of motor innervation of the chick wing does not depend upon the segmental origin of muscles. Development. 1987;99:565-75.

266. Lance-Jones C, Landmesser L. Motoneurone projection patterns in the chick hind limb following early partial reversals of the spinal cord. J Physiol. 1980; 302:581-602.

267. Tosney KW, Landmesser LT. Development of the major pathways for neurite outgrowth in the chick hindlimb. Dev Biol. 1985;109:193-214.

268. Hamburger $V$. The effects of wing bud extirpation on the development of the central nervous system in chick embryos. J Exp Zool. 1934;68:449-94.

269. Tosney KW, Landmesser LT. Pattern and specificity of axonal outgrowth following varying degrees of chick limb bud ablation. J Neurosci. 1984;4: 2518-27.

270. Tosney KW, Landmesser LT. Specificity of early motoneuron growth cone outgrowth in the chick embryo. J Neurosci. 1985;5:2336-44.

271. Noguchi K, Ishikawa R, Kawaguchi M, Miyoshi K, Kawasaki T, Hirata T, et al. Expression patterns of Sema3A in developing amniote limbs: with reference to the diversification of peripheral nerve innervation. Develop Growth Differ. 2017:59:270-85

272. Liu Y, Sugiura Y, Wu FF, Mi WT, Taketo MM, Cannon S, Carroll T, Lin WC. $\beta$ Catenin stabilization in skeletal muscles, but not in motor neurons, leads to aberrant motor innervation of the muscle during neuromuscular development in mice. Dev Biol. 2012;366:255-67.

273. Wu HT, Lu YS, Barik A, Joseph A, Taketo MM, Xiong WC, Mei L. $\beta$-catenin gain of function in muscles impairs neuromuscular junction formation. Development. 2012;139:2392-404.

274. Wu HT, Xiong WC, Mei L. To build a synapse: signaling pathways in neuromuscular junction assembly. Development. 2010;137:1017-33.

275. Lichtman JW, Colman H. Synapse elimination and indelible memory. Neuron. 2000;25:269-78.

276. Lin WC, Sanchez HB, Deerinck T, Morris JK, Ellisman M, Lee KF. Aberrant development of motor axons and neuromuscular synapses in erbB2 deficient mice. Proc Natl Acad Sci. 2000:97:1299-304.

277. Barik A, Li L, Sathyamurthy A, Xiong WC, Mei L. Schwann cells in neuromuscular junction formation and maintenance. J Neurosci. 2016;36:9770-81.

278. Wang J, Song F, Loeb JA. Neuregulin1 fine-tunes pre-, post-, and perisynaptic neuromuscular junction development. Dev Dyn. 2017;246:368-80.

279. Yumoto N, Kim N, Burden SJ. Lrp4 is a retrograde signal for presynaptic differentiation at neuromuscular synapses. Nature. 2012;489:438-42.

280. Shellswell GB. The formation of discrete muscles from the chick wing dorsal and ventral muscle masses in the absence of nerves. J Embryol Exp Morph. 1977:41:269-77.

281. Lance-Jones C, Landmesser L. Motoneurone projection patterns in embryonic chick limbs following partial deletions of the spinal cord. J Physiol. 1980;302:559-80.

282. de Lima JE, Bonnin MA, Birchmeier C, Duprez D. Muscle contraction is required to maintain the pool of muscle progenitors via YAP and NOTCH during fetal myogenesis. elife. 2016;5:e15593.

283. Havis E, Bonnin MA, de Lima JE, Charvet B, Milet C, Duprez D. TGF $\beta$ and FGF promote tendon progenitor fate and act downstream of muscle contraction to regulate tendon differentiation during chick limb development. Development. 2016;143:3839-51.

284. Blitz E, Viukov S, Sharir A, Shwartz Y, Galloway JL, Pryce BA, et al. Bone ridge patterning during musculoskeletal assembly is mediated through SCX regulation of Bmp4 at the tendon-skeleton junction. Dev Cell. 2009;17: 861-73.

285. Van Valen L. A study of fluctuating asymmetry. Evolution. 1962;16:125-42.

286. Palmer AR, Strobeck C. Fluctuating asymmetry: measurement, analysis, patterns. Annu Rev Ecol Syst. 1986;17:391-421.

287. Birmingham A. Homology and innervation of the Achselbogen and pectoralis quartus, and the nature of the lateral cutaneous nerve of the thorax. J Anat Physiol. 1889;23:206-23.

288. Ruge G. Der Hautrumpfmuskel der Säugetiere: der M. sternalis und der Achselbogen des menschen. Gegenbaurs Morphol Jahrb. 1905;33:379-531.
289. Zuckerkandl E. Zur Anatomie und Morphologie der Musculi Pectorales. Sitzber kaiserl Akad Wien. 1910;119:469-558.

290. Wilson JT. The innervation of the achselbogen muscle. J Anat Physiol. 1912; 47:8-17.

291. Ura R. Über die allgemeine Differenzierung der oberflächlichen Brustmuskeln mit besonderer Berücksichtigung der Hautrumpfmuskeln der Säugetiere. Mitt Med Ges Tokyo. 1937;51:216-88 339-390.

292. Kida MY, Kudoh H. Innervation of the sternalis muscle accompanied by congenital partial absence of the pectoralis major muscle. Okajimas Folia Ana Jpn. 1991;67:449-56.

293. Sawada M. Muscular and tendinous arches of the axilla, with special reference to the comparison of the morphological features in human fetuses and adults. Hirosaki Med J. 1994;45:317-26.

294. Jelev L, Georgiev G, Surchev L. The sternalis muscle in the Bulgarian population: classification of sternales. J Anat. 2001:199:359-63.

295. Simhadri D, Suseelamma D, Praveen Kumar M. Uncommon variation in muscuature of the chest wall. Anat Physiol. 2012;2:113.

296. Maxwell EE, Larsson HCE. Osteology and myology of the wing of the emu (Dromaius novaehollandiae), and its bearing on the evolution of vestigial structures. J Morphol. 2007;268:423-41.

297. Hirasawa T, Fujimoto S, Kuratani S. Expansion of the neck reconstituted the shoulder-diaphragm in amniote evolution. Develop Growth Differ. 2016;58: $143-53$.

298. Eisler P. Die Muskeln des Stammes. In: Bardelben KH, editor. Handbuch der Anatomie des Menchen, band 2. Jena: Gustav Fischer; 1912. p. 1-662.

299. Nishi S. Muskeln des Rumpfes. In: Bolk L, Göppert E, Kallius E, Lubosch W, editors. Handbuch der vergleichenden Anatomie der Wirbeltiere, band 5. Berlin: Urban und Schwarzenberg; 1938. p. 351-446.

300. Ghiora A. Associated movements between diaphragma and upper limb muscles in a case of Erb's palsy. Confin Neurol. 1933;13:120-3.

301. Robinson PK. Associated movements between limb and respiratory muscles as sequel to brachial plexus birth injury. Bull Johns Hopkins Hosp. 1951;89:21-9.

302. Sargent F. Birth injury of left arm showing crossed re-innervation from phrenic nerve into nerves supplying biceps, extensor digitorum communis and other muscles. Proc R Soc Med. 1950;43:252.

303. Oosuga T. Development of diaphragma of Xenopus laevis in sight of comparative myology. Kitakanto Med J. 1969;19:375-95.

304. Jenkins FA, Weijs WA. Functional anatomy of the shoulder in the Virginia opossum (Didelphis virginiana). J Zool. 1979;188:379-410.

305. Nagashima H, Hirasawa T, Sugahara F, Takechi M, Usuda R, Sato N, Kuratani $\mathrm{S}$. Origin of the unique morphology of the shoulder girdle in turtles. J Anat. 2013:223:547-56.

Ready to submit your research? Choose BMC and benefit from:

- fast, convenient online submission

- thorough peer review by experienced researchers in your field

- rapid publication on acceptance

- support for research data, including large and complex data types

- gold Open Access which fosters wider collaboration and increased citations

- maximum visibility for your research: over $100 \mathrm{M}$ website views per year

At $\mathrm{BMC}$, research is always in progress.

Learn more biomedcentral.com/submissions 